\title{
RETHINKING WELFARE RIGHTS: RECIPROCITY NORMS, REACTIVE ATTITUDES, AND THE POLITICAL ECONOMY OF WELFARE REFORM
}

\author{
AMY L. WAX* \\ I \\ INTRODUCTION
}

A spate of recent reports on President Clinton's 1996 welfare reform initiative, the Personal Responsibility and Work Opportunity Reconciliation Act ("PRA"), indicates that the new welfare regime appears to be working. Although results vary by state, welfare rolls have dropped dramatically as many former recipients have gone to work. ${ }^{1}$ It remains to be seen whether the welfare population is better off and whether current trends will persist if the economy slows down. ${ }^{2}$ For the time being, welfare reform correlates with reduced dependency on federal poor relief programs.

The public also seems pleased with the new welfare system. Public opinion surveys consistently reveal staunch support for key features of President Clinton's reform initiative, including work requirements for the able-bodied and time limits on benefits. ${ }^{3}$ A majority of voters approve of providing services

Copyright (C) 2000 by Amy L. Wax

This article is also available at http://www.law.duke.edu/journals/63LCPWax.

* Professor of Law, University of Virginia.

1. See Raymond Hernandez, Most Off Welfare Get Jobs, But Not All Long Term, N.Y. TimES, Aug. 5, 1999, at A1 (citing a Rockefeller Institute study that followed 9000 single mothers leaving the welfare rolls and found that two-thirds found jobs within a year); Hanna Rosin \& John F. Harris, Welfare Reform Is On a Roll: Working Poor Still Struggle, Study Says, WASH. Post, Aug. 3, 1999, at A1 (citing an Urban Institute study showing that welfare rolls have shrunk more than expected and a Council of Economic Advisors report attributing a significant portion of this drop to 1996 welfare reforms); see also GENERAL ACCOUNTING OFFICE, REPORT TO CONGRESSIONAL COMMITTEES, WELFARE REFORM: ASSESSING THE EFFECTIVENESS OF VARIOUS WELFARE-TO-WORK APPROACHES (Sept. 9 1999) [hereinafter GAO REPORT] (documenting the drop in rolls and the transition of former welfare recipients to employment); DEP'T OF HEALTH AND HUM. SERVICES, TEMPORARY ASSISTANCE FOR NEEDY FAMILIES PROGRAM, SECOND ANNUAL REPORT TO CONGRESS 34-47 (Aug. 1999) [hereinafter HHS REPORT] (showing that most states are meeting work participation rate requirements).

2. See Associated Press, Study Says Welfare Changes Made the Poorest Worse Off, N.Y. TIMES, Aug. 23, 1999, at A13 (reporting that between 1993 and 1995, the poorest 20\% of single parent households headed by women "lost an average of $\$ 577$ a year, with incomes falling to $\$ 8,047$ annually").

3. See, e.g., Ronald Brownstein, National Perspective Welfare Reform Makes a Case for Boosting Welfare of Working Poor, L.A. TIMES, Aug. 16, 1999, at A5 (citing a 1998 poll of Democrats that found $74 \%$ support for maintaining recently instituted time limits on welfare benefits); Kevin McCabe \& Vernon Smith, Who Do You Trust, 23 BosTON REV. 25 (1998) (noting a 1995 CBS/New York Times survey in which $89 \%$ supported a mandated work requirement for welfare recipients); see also STEVE FARKAS ET AL., THE VALUES WE LIVE BY: What AMERICANS WANT FROM WELFARE REFORM 16, 
such as job training, child care, child support collection, short-term loans, and transportation subsidies that help the poor become self-supporting. The new welfare reform package gives states the flexibility to make those services available.

Although the public staunchly supports President Clinton's welfare reform initiative, the academy has been somewhat more critical. ${ }^{4}$ What is notably missing from the critique, however, is any call to place support for the poor on a more secure legal footing. No significant voice in the debate today argues that so-called "economic rights" should be elevated to constitutional status. The debate proceeds almost entirely in terms of ordinary, or normal, politics. ${ }^{5}$

This is not surprising. Establishing an unassailable right to welfare was once an important goal of legal academics and activists, but is no longer. Initially, the objective was not to amend the Constitution, but to identify within it previously unrecognized, positive entitlements for citizens and affirmative duties for government. ${ }^{6}$ Although academicians still make fitful efforts along these lines, ${ }^{7}$ liti-

44-46 (1996) (documenting majority support for time limits and work requirements). $C f$. MARTIN

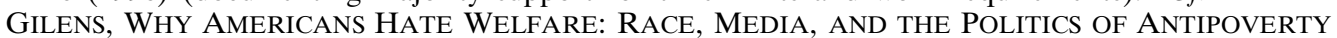
POLICY 189 (1999) (noting that support for time limits is somewhat equivocal because voters recognize that individual circumstances may make them harsh for some).

The key features of the Clinton plan are a phased-in schedule of work requirements for recipients of federal cash assistance and a lifetime limit on benefits. Generally, persons receiving benefits are required to work at private or workfare jobs for a designated number of hours each week after two years on welfare. States may impose a stricter work schedule, but may also exempt up to one-fifth of recipients from work requirements. There is also a firm five-year lifetime limit on benefits, which states may shorten at their option. For PRA requirements, see, e.g., DAN BLOOM, AFTER AFDC: WELFARE-TOWORK CHOICES AND CHALLENGES FOR STATES 91-97, at 113-16 (1997) (describing states' options and detailing work participation rate requirements for states); HHS REPORT, supra note 1, at 8, 139-40, 171-81 (reporting that currently 20 states require immediate participation in work, six require participation between 45 days and six months of receipt of cash assistance, 23 require participation within 24 months, and two within other timeframes, and noting that 28 states impose the federal five-year time limit, six states use "intermittent" time limits, eight states use shorter limits, five use options involving supplements for families exceeding the five-year limit, and five are applying limits for adults only).

4. See, e.g., Peter Edelman, Lawyering for Poor Communities in the Twenty-First Century, Seventh Annual Stein Center Symposium on Contemporary Urban Challenges, 25 FORDHAM URB. L.J. 685, 685 (1998) (deploring that "[s]tatutory frameworks governing the poor are less and less friendly"); Peter Edelman, The United Nations Convention on the Rights of the Child: Implications for Welfare Reform in the United States, 5 GEO. J. FIGHTING POVERTY 285, 286 (1998) (challenging the conventional wisdom that shrinking welfare rolls reflect the success of welfare reform). See generally Sheryll Cashin, Federalism, Welfare Reform, and the Minority Poor: Accounting for the Tyranny of State Majorities, 99 COLUM. L. REV. 552 (1999) (criticizing welfare reform generally and devolution of authority to the states in particular).

5. See generally Bruce Ackerman, We the People (1991) (distinguishing between constitutional politics, which results in changes to the fundamental charter of government, and "normal" or "ordinary" politics, which is the process of legislative or executive decisionmaking within the existing constitutional framework).

6. See, e.g., Charles L. Black, Jr., Further Reflections on the Constitutional Justice of Livelihood, 86 COLUM. L. REV. 1103 (1986) (proposing to ground a constitutional right to welfare in the preamble's reference to "the general welfare" and the rights to life and happiness featured in the Declaration of Independence); Thomas C. Grey, Procedural Fairness and Substantive Rights, in DUE PROCESS 182 (J. Roland Pennock \& John W. Chapman eds., 1977) (locating an implicit right to welfare in the idea of due process); Frank I. Michelman, States' Rights and States' Roles: Permutations of "Sovereignty" in National League of Cities v. Usery, 86 YALE L.J. 1165 (1977) (suggesting a constitutional welfare right may be derived from the Supreme Court's state sovereignty jurisprudence); Frank I. Michelman, The 
gators rarely do. ${ }^{8}$ The diminishing interest in this project is partly a product of the courts' decisive rejection of the notion that the federal Constitution, as currently written, requires government to reduce inequality and relieve want. ${ }^{9}$

Consequently, proponents of a right to basic economic security have all but given up on constitutional exegesis in favor of normative ideal theory. Drawing on liberal theorists like John Rawls and Ronald Dworkin, scholars have asked what a liberal, democratic society should provide by way of assistance to the least well off or, even more broadly, to all its citizens. These discussions implicitly recognize that our present system diverges from what a liberal society de-

Supreme Court, 1968 Term-Foreword: On Protecting the Poor Through the Fourteenth Amendment, 83 HARV. L. REV. 7 (1969) (arguing that the Equal Protection Clause extends logically to the protection of certain minimum entitlements); Frank I. Michelman, Welfare Rights in a Constitutional Democracy, 1979 WASH. U. L.Q. 659 (attempting to apply John Hart Ely's process-based theory of constitutional interpretation to derive welfare rights); Lawrence Gene Sager, Fair Measure: The Legal Status of Underenforced Constitutional Norms, 91 HARV. L. REV. 1212 (1978) (relying on a thesis of underenforcement to argue that Supreme Court decisions do not negate the existence of a constitutional right to welfare within valid, constitutionally sanctioned norms); Laurence H. Tribe, Unraveling National League of Cities: The New Federalism and Affirmative Rights to Essential Government Services, 90 HARV. L. REV. 1065 (1977) (suggesting that the Supreme Court's protection of states' interests against the federal government reflects constitutional deference to popular expectations, including welfare rights); see also Martha F. DAVIS, BRUtAl NeED: LAWYers AND thE Welfare Rights MOVEMENT, 1960-1973 (1993) (tracing the evolution of poverty-law litigation strategies); R. SHEP MELNICK, BETWEEN THE LINES: INTERPRETING WELFARE RIGHTS (1994) (suggesting that statutory arguments are more likely to secure broad welfare rights than those resting on constitutional interpretation); Matthew Diller, Poverty Lawyering in the Golden Age, 93 MICH. L. REV. 1401 (1995) (concluding that the future of poverty-law litigation is one of small victories rather than a dramatic sea change in constitutional interpretation); Edward V. Sparer, The Right to Welfare, in THE RIGHTS OF AMERICANS: WHAT THEY ARE-WHAT THEY SHOULD BE 65 (Norman Dorsen ed., 1971) (discussing the Supreme Court's reluctance to announce a minimum welfare right).

7. See, e.g., Akhil Reed Amar, Forty Acres and a Mule: A Republican Theory of Minimal Entitlements, 13 HARV. J.L. \& PUB. POL'Y 37 (1990) (suggesting that the Reconstruction Amendments imply a welfare right); Susan Bandes, The Negative Constitution: A Critique, 88 MICH. L. REV. 2271 (1990) (arguing that the traditional view according to which the Constitution protects only negative liberties rests on the faulty assumption that the public and private spheres are neatly separable); Erwin Chemerinsky, Making the Right Case for a Constitutional Right to Minimum Entitlements, 44 MERCER L. REV. 525 (1993) (suggesting ways around the traditional assumption that the Constitution does not guarantee affirmative rights); James E. Fleming, Constructing the Substantive Constitution, 72 TEX. L. REV. 211 (1993) (using John Rawls's theories to ground a constitutional interpretation that justifies the constitutional protection of welfare rights); William E. Forbath, Why Is This Rights Talk Different from All Other Rights Talk? Demoting the Court and Reimagining the Constitution, 46 STAN. L. REV. 1771 (1994) (using historical and moral arguments to construct a defense of constitutional welfare rights).

8. See, e.g., Diller, supra note 6, at 1417-24.

9. A recent article in the Harvard Law Review is typical of the abandonment by academics (and poverty activists) of any attempt to interpret the federal Constitution to confer a right to support by the government. Helen Hershkoff, a former high-profile anti-poverty litigator, shifts the battleground away from the federal Constitution, arguing that courts should take a more activist approach to state constitutional provisions imposing affirmative obligations to provide for the poor. See generally Helen Hershkoff, Positive Rights and State Constitutions: The Limits of Federal Rationality Review, 112 HARV. L. REV. 1131 (1999). See also Helen Hershkoff, Welfare Devolution and State Constitutions, 67 FORDHAM L. REV. 1403 (1999) (arguing that state courts need not model their interpretations of state constitutional welfare rights provisions on the Supreme Court's interpretation of the federal Constitution); William C. Rava, State Constitutional Protections for the Poor, 71 TEMP. L. REV. 543 (1999) (detailing various state constitutional protections for welfare rights, but concluding that state courts, influenced by federal standards of constitutional interpretation, are not likely to give much force to these provisions). 
fensible on first principles might recommend. ${ }^{10}$ Ours is a regime that permits, but does not require, quite extensive redistribution of resources. As such, the choice of whether and how to aid the poor is not built into the basic political order, but rather is relegated to ordinary, or normal, processes of democratic governance. ${ }^{11}$

The normative and theoretical questions of what entitlements citizens should have and what duties liberal democratic governments should assume are clearly distinct from the issue of what legal and institutional status should be accorded obligations and rights. Perhaps liberal democratic societies, to be regarded as just, should make some provision for the poor. Does it follow that such provision should be guaranteed as part of the constitutional order? Even theorists who attempt to justify affirmative economic rights as a fundamental component of just liberal societies differ in their views of how those economic rights should be secured, and who should have the authority to decide upon their precise contours. ${ }^{12}$ Nonetheless, the belief is currently widespread that welfare programs for the poor in particular, and programs of economic redistribution in general, are quite important and even central to the basic well-being of citizens. It is not immediately apparent, and it is no easy question, why economic rights should not be regarded as fundamental and given as much protection as other entitlements in our basic charter of government. ${ }^{13}$

10. For example, our political order almost certainly is not the one contemplated in John Rawls's political theory, if only because we tolerate sharp inequalities that do nothing to help the least well-off, thus violating his "difference" principle. See JOHN RAWLS, A THEORY OF JusTiCE 75-83, 150-61 (1971) ("Assuming the framework of institutions required by equal liberty and fair equality of opportunity, the higher expectations of those better situated are just if and only if they work as part of a scheme which improves the expectations of the least advantaged members of society." Id. at 75.).

11. This article uses the term "ordinary politics" without explication because an exploration of the normative and positive aspects of our majoritarian democratic system is beyond its scope. Scholars have arrived at no definitive consensus on how majoritarian politics really ought to work and what an untainted expression of majority sentiment would look like. See, e.g., Einar Elhauge, Does Interest Group Theory Justify More Intrusive Judicial Review, 101 YALE L.J. 31, 34 (1991) (asserting that "any defects in the political process identified by interest group theory depend on implicit normative baselines and thus do not stand independent of substantive conclusions about the merits of particular political outcomes"). Cf. Cashin, supra note 4 (arguing that key features of poverty programs should be fixed at the federal, rather than the state, level because the state politics of welfare are plagued by undesirable "distortions," but failing to identify the hallmarks of undistorted welfare politics).

12. See Robert L. Hale, Freedom Through Law: Public Control of Private GOVERNING POWER 385-99 (1952) (arguing against inviolate property rights, and concluding that the legislature is free to balance various property and liberty interests); RAWLS, supra note 10, at 195-201 (placing principal responsibility for adopting policies consistent with economic justice on the legislature, which has access to information about specific social and economic characteristics of the society).

13. See, e.g., BARBARA Fried, The Progressive Assault on LAISSEZ FAIRE : Robert HALE AND THE FIRST LAW AND ECONOMICS MOVEMENT (1998) (describing Robert Hale's realist critique of the traditional distinction between public and private activity and negative and positive rights); STEPHEN HOLMES \& CASS R. SUNSTEIN, THE COST OF RIgHTS: WHY LIBERTY DEPENDS ON TAXES 199-203 (1999) (suggesting there is no principled basis for distinguishing between positive or affirmative rights, such as the right to basic support by government, and traditional negative liberties enshrined in the Constitution); Charles A. Reich, The New Property, 73 YALE L.J. 733 (1964) (arguing that benefits conferred by government are as vital to freedom and security as traditional forms of property); see also CASs R. SunStein, THE PARTIAL CONSTITUTION 69-75 (1993); Bandes, supra note 7 (attacking the distinction between positive and negative rights); Forbath, supra note 7 (same); William W. Van Alstyne, The Demise of the Right-Privilege Distinction in Constitutional Law, 81 HARV. L. REV. 1439, 
This article seeks a fresh perspective on the old question of whether our federal Constitution should properly include a right to basic economic security. Assuming such rights are not currently protected, are there reasons to favor constitutionalizing welfare within our political and economic system? It is generally assumed that constitutional rights stand as countermajoritarian guarantees against the forces of ordinary politics. In theory, they should serve as trumps, or inviolate protections, against majority will. ${ }^{14}$ Of course, they need not function in this way. At any point in time, most voters may approve of what the Constitution requires. In that case, the countermajoritarian function is, in effect, superfluous. However, the conventional understanding is that constitutionalization at least offers the potential for sheltering entitlements from majority will. Proponents of elevating an entitlement to constitutional status might therefore base their position on some account of why entrusting a matter to the political majority would be unwise or unjust, or would undermine important objectives or values.

Whether writing welfare rights into the Constitution would even potentially make any difference to anyone depends on what is meant by that designation. Social assistance programs in modern welfare states fall into two general categories. The first is modelled on social insurance, with contributions most often tied to employment. The second is categorical assistance based on need. Needbased assistance is the dominant model for poor relief at all levels of government in this country today. But the term "need," both in ordinary discourse and as used to describe programs and policies, is notoriously slippery. "Need" admits of at least two possible meanings: One is static and asset-based. It looks only to resources and not to the potential for self-help. The other is a more dynamic conception that takes into account history and volition. On the latter view, need-based aid would be denied to those who could take steps to avoid destitution or could properly be held responsible for the persistence of their situation. On an even more stringent view, destitution due to improper or irresponsible past behaviors would negate need, even if self-help were currently out of reach. Dynamic notions of economic need give rise to the age-old distinction between the deserving poor (who are traditionally considered entitled to assistance) and the undeserving poor (who are not). ${ }^{15}$

1461-62 (1968) (outlining the unraveling of the traditional distinction between rights and privileges). But see, e.g., DAVID KELlEY, A LIFE OF ONE's OWN: INDIVIDUAL RIGHTS AND THE WELFARE STATE (1998) (arguing that government should protect only negative rights); Robert H. Bork, Commentary: The Impossibility of Finding Welfare Rights in the Constitution, 1979 WASH. U. L.Q. 695; Richard Epstein, The Uncertain Quest for Welfare Rights, 1985 BYU L. REV. 201; Ralph K. Winter, Jr., Changing Concepts of Equality: From Equality Before the Law to the Welfare State, 1979 WASH. U. L.Q. 741; Ralph K. Winter, Jr., Poverty, Economic Equality, and the Equal Protection Clause, 1972 SUP. CT. REV. 41.

14. See, e.g., RonAld DwORKIN, TAKING Rights SERIOUSLY xi (1977) ("Individual rights are political trumps held by individuals."); Cass R. Sunstein, Rights and Their Critics, 70 NOTRE DAME L. REV. 727, 736-39 (1995) (discussing the conception of rights as trumps).

15. See, e.g., DAVID SchmidTz \& Robert E. GoOdin, SocIAL WElfare AND INDIVIDUAL RESPONSIBILITY 4-7 (1998) (introducing the distinction between static and dynamic views of poverty and linking these views to ideas of the deserving and undeserving poor). 
Support for a basic right to government assistance need not entail the rejection of these traditional categorical distinctions. It is possible to conceive of a constitutional provision that recognizes an indefeasible right to government help, but only for those in need through no fault of their own or who consent to work in exchange for assistance. Historically, however, advocates of a constitutional entitlement to economic security have favored a robust protection that does not impose stringent tests of need or serious obligations on the poor. ${ }^{16}$ These advocates have recognized that constitutionalization at least provides the potential to downplay or even banish the deserving/undeserving distinction from the arena of poor relief. The push to enshrine welfare rights in the constitution has thus come to be identified, if not logically then ideologically, with something like an unconditional right to government aid-as with an entitlement to a basic income regardless of need, or an automatic need-based transfer regardless of opportunities for self-help. ${ }^{17}$

In asking whether we should give constitutional recognition to basic economic rights as so defined, this article leaves aside the difficult normative question of what kinds of welfare programs justice requires in a liberal democratic society. ${ }^{18}$ Nor does it address the myriad institutional objections that might be made against elevating welfare rights to constitutional status. ${ }^{19}$ Rather, it examines the consequences of creating a constitutional right to welfare by contrasting that state of affairs with the expected outcome of ordinary politics. It proceeds by developing a theory of how voters will tend to think about government welfare programs by looking to expected reactions to individuals' dependence on others' productive efforts. It predicts that voters generally will be

16. See, e.g., DAVIS, supra note 6; MELNICK, supra note 6.

17. See, e.g., MARTin Anderson, Welfare: The Political ECONOMY OF Welfare ReForm IN THE UNITED STATES (1978) (providing a history of guaranteed income proposals and empirical work on their effects on behavior); SAMUEL BRITTAN \& STEVEN WEBB, BEYOND THE WELFARE STATE: AN EXAMINATION OF BASIC INCOMES IN A MARKET ECONOMY (1990) (arguing for guaranteed basic income); PHILIPPE VAN PARIJS, ARguING FOR BASIC INCOME: ETHICAL FOUNDATIONS FOR A RADICAL REFORM (1992); PHILIPPE VAN PARIJS, REAl FreEdOM FOR All: What (IF ANYTHING) CAN JUSTIFY CAPITALISM? 32-35 (1995) (arguing that "real-freedom-for-all" requires the government to provide the highest universal unconditional income for all "consistent with ... selfownership"); Anne L. Alstott, Work vs. Freedom: A Liberal Challenge To Employment Subsidies, 108 YALE L.J. 967, 981, 990-92 (1999) (discussing van Parijs's suggestion that justice requires a liberal regime to pay a basic, universal, guaranteed income at the highest sustainable level). Van Parijs favors giving all citizens a basic income regardless of work effort or earnings. A more restrictive form of basic income, of which President Nixon's proposed Family Assistance Plan is an example, provides for a broad-based means-tested transfer with a phase-out as earnings increase. The only requirement for receiving aid under the Nixon plan was low earnings, regardless of the reason for "need." A meanstested program can be structured as a cash grant or negative income tax and is cheaper than a straight, universal, guaranteed income, but creates rather different behavioral and economic incentives. See generally VAN PARIJS, REAL FREEDOM, supra, and VAN PARIJS, ARGUING FOR BASIC INCOME, supra.

18. See generally Amy L. Wax, Something for Nothing: the Liberal Case Against Welfare Work Requirements (unpublished manuscript, on file with author).

19. These objections relate to the effect on the balance of power among the three branches of government, the courts' competence to administer positive entitlements, and the compatability of a right to government financial assistance with other features of our economy, our system of government, or the pre-existing constitutional order. See, e.g., KELlEY, supra note 13; Hershkoff, Positive Rights, supra note 9. 
hostile to such dependency unless those seeking support have made a goodfaith effort to escape poverty and have exhausted all reasonable means of supporting themselves. It investigates whether this theory squares with voters' professed views. It suggests that fundamental and innate attitudes which have evolved over millennia to facilitate group sharing and cooperation exert a strong influence on popular attitudes towards poor relief and towards social welfare policies generally in democratic societies. A deep-seated expectation of reciprocal cooperation from group members and a reflexive hostility to those who would free-ride on others' productive efforts may help explain the tenacious distinction between the deserving and undeserving that pervades the politics of redistribution of government resources. Although mandates that run contrary to this ideology may be economically feasible in advanced industrial societies, such programs are unlikely to receive the long-term support of the citizenry. An unconditional promise of generous economic assistance at public expense will strike most citizens as unfair and will therefore meet staunch resistance form the great majority of voters. Although constitutionalization would appear to be the ideal device for resisting majority sentiment in this area, that device probably will not work. Recent scholarship suggests that constitutional provisions cannot long resist popular will. That may be especially true of entitlements that flout fundamental moral categories and run contrary to basic notions of fairness.

II

\section{POOR RELIEF AS A MUTUAL AID "GAME”}

The analysis begins with the premise that centralized systems of social assistance, which are a cardinal feature of the modern welfare state, have taken over a role that private, informal institutions used to play in more remote periods of human history. Welfare programs can be viewed as establishing a pool of resources, drawn from common assets, to protect citizens against misfortune, hardship, and the vicissitudes of economic life. To this extent, welfare programs bear some loose resemblance to private mutual insurance funds, which were a common feature of nineteenth and twentieth century working life. ${ }^{20}$ To create these institutions, workers raised money by collecting a small sum from each individual in the group. Each member then became entitled to draw from the pool of resources upon the occurrence of an event that deprived the person of an independent means of livelihood or gave rise to some special need, such as illness, loss of employment, or family disaster.

20. See, e.g., KELLEY, supra note 13, at 31-61 (discussing the historical process by which government-sponsored welfare programs replaced private mutual aid orgainizations); MARVIN OLASKY, THE TRAGEDY OF AMERICAN COMPASSION (1992); SCHMIDTZ \& GOODIN, supra note 15, at 63-72 (describing the history of friendly societies before the rise of the welfare state and suggesting that these organizations successfully collectivized responsibility). See generally ROBERT SUGDEN, THE ECONOMICS OF RIGHTS, CO-OPERATION, AND WELFARE (1986). 
These "friendly societies" or "sickness clubs" were voluntary, informal schemes held together by members' mutual cooperation. ${ }^{21}$ There was no centralized mechanism for enforcing compliance with the organization's requirements. Maintaining a viable fund under these circumstances was a variation on the well-known "commons" problem. ${ }^{22}$ The challenge was to avoid the "tragedy of the commons" that resulted from members withdrawing too many resources and contributing too little to the common asset. To forestall this sequence, the insurance group had to devise and adhere to rules that ensured a stable balance between withdrawal and contribution, and that persuaded members to stay within the group.

The economist Robert Sugden has suggested that informal, voluntary group insurance funds, resembling traditional friendly societies, can be modeled as a multi-round, mutual insurance game..$^{23}$ The rules of Sugden's "mutual aid" game dictate that each participant must contribute (that is, function as a "cooperator" or "donor") on each round of the game, unless he qualifies as a "recipient" by suffering some chance setback that entitles him or her to withdraw from the fund. As Sugden notes, it is open to individual members of the mutual aid collective to adopt different strategies for playing the game as a function of what others in the group do. Sugden shows that defection on every round is an equilibrium strategy for playing the game. It is always rational for a member to "defect"- that is, to refuse to contribute to the fund on any given round-for the same reason it is rational to defect in the prisoner's dilemma game. The payoffs to individuals are higher when they can withdraw from the fund in an emergency without contributing anything to the fund's maintenance. As with the prisoner's dilemma, it makes sense for each individual not to cooperate (that is, to fail to pay into the fund even if able to do so), regardless of what others do. If all adopt this strategy, however, the fund will soon dwindle and collapse.

Maintaining a viable mutual insurance fund, like enforcing cooperation in the prisoner's dilemma, poses a collective action problem: If all rationally choose to defect, all are worse off than if everyone cooperated. But cooperation is not an individually rational strategy. Some mechanism is needed to en-

21. See, e.g., MichaEl HeCHTER, PrinciPles OF Group SOLIDARITY 113-14 (1987).

22. See, e.g., SCHMIDTZ \& GOODIN, supra note 15, at 53-58, 60-72 (suggesting that preserving the integrity of mutual aid societies is a variant on the commons problem). See generally ELINOR OSTROM, GOVERNING THE COMMONS: THE EVOLUTION OF INSTITUTIONS FOR COLLECTIVE ACTION (1990).

23. SugDEN, supra note 20, at 122-28. According to Sugden, each round of the game is played as follows:

One player is chosen at random to be the recipient; each player has the same probability $1 / \mathrm{n}$ of being chosen. The other players are the donors. Then each donor has a choice between two moves, "co-operate" and "defect." If he co-operates, he scores -c; if he defects, he scores zero. The recipient scores $\mathrm{Nb}$ where $\mathrm{N}$ is the number of donors who have co-operated, and where $\mathrm{b}<\mathrm{c}$. The idea, then, is that each person has a chance of being in a situation (say sickness) in which he needs the help of the others, and that the benefit he then derives from each other person's act of assistance is greater than the cost to him of assisting another person, when that person is in need.

Id. at 123-24. 
force cooperation. In the case of mutual insurance, the collective-action problem is potentially surmountable because the insurance fund is not a public good. ${ }^{24}$ An individual who fails to contribute his or her fair share is conspicuous to others and can be excluded from participation on the terms that would otherwise apply. Specifically, he or she can be barred from receiving funds when tragedy strikes. In accordance with this possibility, Sugden shows that there is another strategy that produces higher payoffs for all players, but only if all (or almost all) players adhere to it. He calls that strategy "T1." Sugden shows that T1, like "always defect," is also an equilibrium strategy for playing the mutual aid game, in that if other players follow T1, then any given player does best by playing $\mathrm{T} 1$ as well. $\mathrm{T} 1$ is a best reply to itself, and a unique best reply. Under T1, members cooperate only with others who have cooperated (that is, contributed their share) on the last round of the game. Cooperation with a player consists in permitting that player to become a recipient when misfortune strikes. As part of the T1 strategy, members refuse to cooperate with "defectors"- that is, those who have failed to cooperate by refusing to make their expected contribution on the last round. Defectors are forbidden to serve as recipients when their turn comes. They are barred from withdrawing mutually-generated resources from the pot. Only individuals in good standing (that is, those who have played their expected role as donors on previous rounds) are allowed to remain eligible to withdraw from the fund.

Sugden describes the T1 convention as one of "multilateral reciprocity and of punishment and reparation." ${ }^{25}$ The "convention of reciprocity," as Sugden terms it, "prescribes that individuals should co-operate with those people who co-operate with them-but not with others." ${ }^{26}$ The convention of punishment dictates that members should always refuse to cooperate with those who do not contribute to the collective and thus attempt to free-ride. If everyone adheres to this convention, a mutually beneficial equilibrium can be achieved. That equilibrium is good for everyone because the maintenance of a collective common fund provides everyone with valuable insurance against risk.

For proponents of informal cooperative self-help, Sugden's mutual insurance model would appear virtuous in two other respects. First, the game he describes violates no libertarian precept, for nothing is taken from anyone against his or her will. In ideal theory, mutual insurance pools are noncoercive in the sense that individuals can choose to withdraw from the collective at any time without sacrificing anything except the benefits of membership. ${ }^{27}$ Second, the voluntariness of these cooperative arrangements guarantees Pareto-

24. See HECHTER, supra note 21, at 116.

25. SuGDEN, supra note 20 at 127.

26. Id. at 146 .

27. This aspect of Sugden's game is highly idealized. Few institutions of civil society fulfill the condition of perfectly voluntary participation with costless and unimpeded exit. Some social institutions based on interdependency, such as families and religious groups, make exit difficult or involve considerable investments and sunk costs and thus create the potential for minority oppression and Paretoinferior, or inefficient, rent-seeking transfers among members. See HECHTER, supra note 21, at 47-49. 
improvement for all members. Members will stay with the organization only as long as they believe they will gain. It follows that, if they achieve a stable equilibrium, such groups are Pareto-efficient. By definition, the group survives if everyone is better off, which occurs only if everyone plays by the rules. According to Sugden, that can happen only if players routinely cooperate with cooperators, but also punish non-cooperators by barring them from receiving assistance out of group resources.

III

\section{Mutual Insurance CoOPERATIVES AND ReACTIVE AtTITUdes}

Sugden's analysis suggests that in an informal arrangement that provides mutual insurance, stability can potentially be achieved if most people accept a convention of "strong reciprocity," which, for our purposes, designates the propensity to cooperate with cooperators and punish would-be free-riders. ${ }^{28} \mathrm{How}-$ ever, it is not immediately obvious why individuals would spontaneously adhere to such a rule if there is no airtight assurance that others will do so as well. ${ }^{29}$ Moreover, punishing free-riders is often costly, which gives rise to free-rider problems of its own as individuals will be tempted to leave enforcement and punishment of defectors to others. ${ }^{30}$

Why might individuals involved in something like a mutual aid collective come to adhere to a norm or convention of strong reciprocity, and why do they honor it even in situations in which that behavior may be costly $?^{31}$ An innate tendency to behave according to a strong reciprocity convention is one possible explanation. If human beings possess a set of reactive attitudes or moral sentiments that impel them to engage in strongly reciprocal behaviors, they will adhere to the reciprocity norm regardless of whether others do so and regardless

28. The economists Samuel Bowles and Herbert Gintis have also used the term "strong reciprocity" to describe a rule, which corresponds in broad outline to Sugden's reciprocity convention, of "cooperat[ion] with others similarly disposed, even at personal cost," and "willingness to punish those who violate... norms, also at personal cost." Samuel Bowles \& Herbert Gintis, Is Equality Passe? Homo Reciprocans and the Future of Egalitarian Politics, 23 B. REV. 26, 26 (1998) [hereinafter Bowles \& Gintis, Homo Reciprocans]; see also Samuel Bowles and Herbert Gintis, Reciprocity, Self-Interest and The Welfare State, _ NORDIC J. OF ECON. (forthcoming).

29. See Sugden, supra note 20; Bowles \& Gintis, Homo Reciprocans.

30. See SUGDEN, supra note 20, at 124-27 (explaining the temptation to externalize the costs of enforcement); see, e.g., Richard H. McAdams, The Origin, Development, and Regulation of Norms, 96 MICH. L. REV. 338, 352-54, 366-75 (1997) (describing the collective-action problem involved in the enforcement of community or extra-legal norms and arguing that the quest for esteem can provide the basis for effective enforcement mechanisms).

31. Bowles and Gintis summarize the results of game-theory experiments which suggest that people have a predisposition to cooperate with those who treat them with generosity and to seek revenge against persons perceived to behave unfairly even in circumstances, such as ultimatum games and public goods experiments, where that behavior is not strictly rational for individual players. See Bowles \& Gintis, Reciprocity, supra note 28, at 1-12. See generally John H. KAGEL \& Alvin E. Roth, THE HANDBOOK OF EXPERIMENTAL ECONOMICS (1995). See also MATT RIDLEY, THE ORIGINS OF VIRTUE: HUMAN INSTINCTS AND THE EVOLUTION OF COOPERATION 127-47 (1997) (discussing scholarly treatments of the psychological and economic underpinnings of cooperation and setting these treatments in an evolutionary context); ROBERT FRANK, PASSIONS WITHIN REASON 163-84 (1988) (describing the "irrational" adherence to norms of fairness). 
of whether it is to their advantage in the short run to adopt this strategy for offering support to others. This tendency, if present in everyone, will function as a mechanism of coordination that will enable individuals to cooperate for mutual advantage.

A repertoire of sentiments that facilitates strong reciprocity may have developed under evolutionary pressure over the lengthy period in which people lived in small groups without strong centralized governments. Under those circumstances, the ability to engage in group cooperation may have carried a distinct adaptive advantage. ${ }^{32}$ The forces of natural selection would operate to favor emotional reactions, psychological predispositions, or cultural practices that fostered adherence to the rule of strong reciprocity, thus facilitating mutual cooperation.

Robert Sugden's mutual-aid thought experiment suggests that a key to the stabilization of some mutually advantageous but voluntary cooperative ventures is the merciless punishment of free-riders. One would expect to find a strong propensity to feel indignation, resentment, and anger toward persons who fail to contribute their fair share. These feelings of resentment would motivate group members to refuse aid to uncooperative individuals and to forbid them from drawing on collective resources. Only those who were willing to contribute, or had contributed in the past as expected, would be permitted to receive aid from the group. ${ }^{33}$ As noted, the impulse to cooperate only with other cooperators and to retaliate against defectors will not be strictly consistent with any players' short-term self-interest, which dictates non-cooperation on every round. The suggestion is that emotions, not rational calculation, drive players to adopt a strongly reciprocal strategy in a setting where group members undertake to provide mutual insurance or aid in case of need. The undercurrent of strong emotions that attend responses to others' conduct within such a setting may enhance everyone's willingness to adhere to the strong reciprocity norm. Players' awareness that others resent any effort to shirk and may retaliate against that behavior will make everyone more willing to play by the rules. In effect, the emotions of resentment toward defectors and solidarity with faithful donors functions as something like a "commitment" mechanism that fosters adherence, and signals an assurance of adherence, to a rule of reciprocity that rewards cooperators and punishes defectors regardless of short-term benefits to the individual. By preventing individuals from acting from pure self-interest and providing a mechanism of coordination, strong emotions make possible mu-

32. See Bowles \& Gintis, Homo Reciprocans, supra note 28, at 4-7 (discussing anthropological evidence of the advantages of group cooperation).

33. Denying funds to defectors and supplying funds to cooperators are not the only measures that could serve to reinforce the reciprocity norm and strengthen the equilibrium in the mutual insurance setting. Other behaviors to enforce group conformity-such as ostracism, refusal to deal, and moral condemnation—can also be brought into play. See, e.g., McAdams, supra note 30. 
tually beneficial forms of social cooperation that would not otherwise spontaneously arise..$^{34}$

\section{GROUP COOPERATION AND THE "DESERVING/UNDESERVING” DISTINCTION}

Robert Sugden's description of the mutual insurance game is indeterminate in important respects. It says little about the precise terms and requirements for participation in a mutual insurance collective under specific economic conditions. Who is expected to contribute (that is, who must function as a donor) and how much? What risks are being insured against? Who is eligible to join the group, and under what circumstances? This section seeks to show how Sugden's insights would apply where group members have access to labor markets. It suggests that where individuals face the choice whether or not to work for pay, an informal scheme of mutual cooperation will tend to adopt the rule that the able-bodied (that is, those who are not obviously incapable of gainful employment) will ordinarily be expected to generate revenues through productive activity and then to contribute a portion of their earnings to the common fund. Eligibility for benefits will be confined to those who, through no fault of their own, are unable to work at all or cannot contribute to the collective by generating a surplus over and above what is necessary to maintain themselves at the most basic level.

It is possible to imagine setting up a common pool mutual aid or mutual "insurance" fund out of which persons can draw if and when they no longer want to work. Disbursing benefits to the voluntarily idle amounts to preserving eligibility to participate in the collective by receiving money from the fund, despite the recipients' deliberate decision not to donate. That would amount to permitting players to choose when and how often to defect from cooperation with no adverse consequences attached. That is equivalent to suspending punishment for refusal to cooperate with the group, which is inconsistent with strong reciprocity. Not only does permitting persons on their own motion to choose whether and when to contribute to the fund amount to abandoning the equilibrium strategy of strong reciprocity, but it can also be regarded as suspending a fundamental feature of the mutual insurance paradigm. By definition, insurance exists to guard against uncontrollable risk. ${ }^{35}$ A mutual aid collective, like any insurance fund, would have a hard time sustaining itself if members were given full discretion to determine how much to contribute and how much to draw out of the common pool. Because the potential for free-riding would be unlimited, the fund would soon run out of money and the cooperative arrange-

34. For an important and ground-breaking discussion of commitment mechanisms, and the role of emotions in motivating behaviors that facilitate mutual cooperation, see FRANK, supra note 31, passim and at 221-26; see also id. at 224 ("The commitment model ... holds that decisions about cooperation are based not on reason but on emotion.").

35. See SUGDEN, supra note 20, at 123-28 (explaining that the mutual insurance game invoves protection against a random event.) 
ment would collapse. In sum, it should be apparent that tolerating voluntary self-qualification for aid is inconsistent with sustaining a voluntary cooperative arrangement designed to provide economic assistance to members in times of need. The stability of such an arrangement would appear to depend on adopting the rule that all able-bodied members-defined as those capable of making a productive contribution-will be expected to work towards enhancing social wealth.

Within the welfare context, the suspension of the rule of reciprocity and the adoption of a rule of self-qualification would correspond to incorporating a static notion of need in which assistance is forthcoming even when poverty is due to unwillingness to work or to work hard enough to support oneself. As already suggested, however, a stable, voluntary, mutual aid society cannot survive the adoption of a principle of unconditional poor relief that allows individuals to decide for themselves whether or not to function as productive members of the group. Rather, informal mutual aid collectives will tend to abide by the rule that those who are able to engage in productive activity must do so, and only those unable to work will be excused. Members must donate to the collective unless they are incapacitated by bad luck, in which case they may qualify as recipients. If work is what enables individuals to contribute, then members will be expected to work - and contribute to the commons-unless they are involuntarily unemployed or rendered incapable of work. The analysis suggests that something roughly like present-day welfare work requirements will be an essential feature of any stable mutual aid game.

\section{ReActive AtTitudes AND THE Psychology of Public Welfare PROGRAMS}

The analysis so far suggests that human beings have evolved a psychology that supports the formation of stable cooperative ventures. The speculation is that those ventures represented a "fitness-enhancing" adaptation. It is possible, for example, that in past primitive environments individuals capable of coming together in stable arrangements of mutual aid had a better chance to survive (and reproduce) than those incapable. The analysis also suggests that, where the purpose of sharing is to insure against economic want, group members will not be allowed to choose when to draw upon the group's resources. A rule of self-qualification will produce a "tragedy of the commons" by encouraging indiscriminate withdrawals from the pool and by prompting group members to defect. Stability of informal cooperative groups requires that members be expected to produce, contribute, and support themselves if they are able to do so, and permits dependency on others only for bad luck, disability, or misfortune. These terms of eligibility amount to adopting a dynamic notion of need that recognizes a distinction between deserving and undeserving beneficiaries.

Although judgmental attitudes based on these distinctions might evolve over time and come to figure quite prominently in informal settings, it does not 
follow that such attitudes will carry over to poor relief schemes mandated by government. As the analysis in Part VIII infra indicates, strong governments can coerce citizens to contribute to others' support without their consent. Because the taxing power can effectively perform the stabilizing function otherwise performed by group norms in informal settings, governments can mandate group-sharing arrangements even on terms that violate reciprocity conventions. In the teeth of political innovations that make continued adherence to the rule of reciprocity unnecessary, will citizens then abandon these norms?

This section suggests that they will not. It argues that norms of strong reciprocity informs citizens' reactions to modern institutions that perform functions similar to informal self-help groups. One premise of evolutionary psychology is that similar social situations trigger common social, emotional, and psychological responses. Arrangements for charging the collective with the economic support of individuals, whether through informal cooperation or within the modern welfare state, will elicit a typical cluster of sentiments because a common psychology underwrites how persons who call upon group assistance are judged by others. In effect, the basic emotions that regulated group cooperation in more primitive environments will continue to dominate our response to more modern arrangements for group responsibility today.

These insights predict that themes of reciprocity and responsibility will loom large in the politics of welfare in modern industrial states. Because citizens who are taxed to support public welfare programs will perceive themselves as being called upon to join a collective for the protection of all, they will be unrelentingly vigilant against evidence of free-riding. They will tend to favor rules that require everyone to contribute as much and draw out as little as they reasonably can. The common theme will be that people must support and help themselves if they are able, and must not allow themselves to become needy if they can avoid it. Those whose dependency is deemed unnecessary, excessive, or avoidable will elicit hostility and indignation. The need to judge what persons seeking benefits can do or have done for themselves or others will drive a keen interest in the behavior and conduct of would-be beneficiaries. Persons who violate the rules against unnecessary dependency on the group will be judged undeserving of public assistance, and the majority will seek to deny them aid. Only persons who are genuinely unable to support themselves, or who have special needs, will be deemed deserving of benefits. Voters will thus frown on policies grounded in a static concept of need and will favor a dynamic conception that takes account of personal effort and conduct. Although the definition of who is able to work may vary with time, place, economics, and culture, it can be predicted that the definition will not be left within the control of potential beneficiaries. ${ }^{36}$ Eligibility will turn on status (such as youth, old age, or par-

36. The tendency to disfavor help for persons needy by choice rather than chance nevertheless leaves room for wide variations in views about when self-help is feasible or reasonable. The demand for reciprocity is thus consistent with a range of cultural and political responses to individual circumstances and with historical shifts on the margins in the categories classified as deserving or undeserving. 
enthood) or luck (illness, disability, or involuntary unemployment), but not on what is perceived to lie within the potential recipients' control. To structure the system otherwise would be to license free-riding, which would elicit the resentment of the group.

Studies of voter preferences provide support for these predictions about attitudes towards public welfare programs. ${ }^{37}$ Based on extensive public opinion surveys, Martin Gilens notes that most voters understand "that people cannot always support themselves," and agree "that when individuals are in need the government has a responsibility to help." ${ }^{38}$ Most want the government to assist those who are genuinely "trying to make it on their own." However, public generosity does not extend to those who take "advantage of the system." voters are unwilling to offer assistance to those who, through lack of diligence or imprudent conduct, are perceived to free-ride on the work of others. Persons who do not try hard enough "to make it on their own" ${ }^{41}$ are viewed with suspicion and disdain. Furthermore, Gilens' surveys suggest that opposition to longstanding welfare policies is based largely on the perception that most welfare recipients do not try hard enough to support themselves. As Gilens summarizes:

the focus of considerable public anger and resentment is not the principle of government support for the needy, but the perception that most people currently receiving welfare are undeserving. While no one factor can fully account for the public's opposition to welfare, the most important single component is this widespread belief that most welfare recipients would rather sit home and collect benefits than work hard to support themselves. ${ }^{42}$

These findings comport with other recent surveys of attitudes toward welfare. A report compiled by the interest group Public Agenda finds that most American voters believe that the government should help the needy but that

The perception of individuals' ability and duty to engage in self-support will tend to vary with factors ranging from dominant notions about determinism versus individual responsibility, to conceptions about the fair economic and personal preconditions for responsible choice, to understandings about individual versus structural causes of poverty and unemployment, to prevailing economic conditions bearing on subgroups' opportunities for self-support and self-betterment, to perceptions about the roles of women and men. For example, the populace may have a very different attitude toward poor relief during the depths of a depression than during boom times. Mothers of young children are more likely to be perceived as deserving if mothers are not generally expected to work and reproduction is viewed either as a right or as inevitable. See infra text accompanying notes 60-76 (discussing welfare policies for single mothers).

37. Bowles and Gintis also discuss the connection between reciprocity norms and modern welfare politics. See Bowles \& Gintis, Homo Reciprocans, supra note 28. These authors also suggest that norms of reciprocity are supplemented by a "basic needs generosity," which recognizes the entitlement of the most destitute to subsistence from the government. Id. at 10-12. It is not clear, however, whether the authors think that this commitment is conditioned on recipients' self-help efforts. If so, basic needs generosity would simply represent a logical extension of reciprocity requirements. Cf., e.g., Stuart White, Three Questions, BosTON REV., Dec. 1998-Jan. 1999, at 22-23.

38. GILENS, supra note 3, at 5.

39. Id. at 8 .

40. Id. at 5 .

41. Id. at $4,4-8$.

42. Id. at 2-3. 
aid should extend only to those who cannot take care of themselves. ${ }^{43}$ Among those expected to work are mothers, whom strong majorities believe should "not be allowed to stay home and care for their children." ${ }^{4}$ This study confirms that although the public has "a sense of responsibility and obligation towards the less fortunate in their society," most voters agree that those seeking assistance must also "assume some obligation in return," must "prove themselves worthy of help," and must "work towards independence." sociologist Alan Wolfe concludes from voter interviews "that there is no belief more strongly held in America than the belief that welfare should go only to those who deserve it." ${ }^{46}$ The deserving include those willing to look diligently for work, to work hard at a job, and to exercise reproductive responsibility. ${ }^{47}$ Likewise, David Miller, in a recent book on social justice, concludes that "the nineteenth-century distinction between the deserving and the undeserving poor is still alive and well." ${ }^{48}$ Based on surveys of attitudes toward welfare in the United States and Britain, Miller states that "people tend to be strongly concerned that the needy not be responsible for their neediness, either in the sense that they have brought their needs upon themselves, or in the sense that they could escape them with a little effort." ${ }^{49}$

As noted, one theme that emerges from these surveys is that most citizens, at least in this country, recognize a collective responsibility to aid the poor. Most express willingness to pay taxes to help those who are genuinely unable to support themselves. ${ }^{50}$ That willingness persists even when conditions make maintaining welfare programs especially expensive or burdensome. Martin Gilens observes that

contrary to popular perceptions, public support for welfare spending does not decline during economic downturns. Hard times ... do not elicit from the middle class a selfinterested concern with minimizing taxes or a resentment over paying for welfare. On the contrary, national economic adversity leads to a greater sense that poor people are the victims of circumstances beyond their control and hence to greater support for welfare. $^{51}$

These observations suggest that voter ideology and normative commitments, rather than rational self-interest narrowly defined, are the primary de-

43. See FARKAS ET AL., supra note 3, at 16-20.

44. Id. at 21.

45. Id. at 17 .

46. Alan Wolfe, One Nation After All: What Middle-Class Americans Really Think About God, COUnTry, FAMily, RACism, Welfare, ImMigration, HomoseXuality, WORK, THE RIGHT, THE LEFT, AND EACH OTHER 204 (1998).

47. See id. at 205-07.

48. David Miller, Principles of Social Justice 76 (1999) (citing N. Jaffe, Attitudes toward Public Welfare Programs and Recipients in the United States, in L.M. SAlamon, Welfare: ThE Elusive CONSENSUS APP. (1978); see also JAMES R. KLUEGEL \& EliOT R. SMITH, BeliefS AbOUT INEQUALITY: AMERICANS' VIEWS OF WhAT IS AND WHAT OUGHT TO BE 152-58 (1986); J. MACK \&

S. LANSLEY, POOR BRITAIN 209-21 (1985).

49. MiLlER, supra note 48 , at 76.

50. See, e.g., WOLFE, supra note 46, at 204.

51. GILENS, supra note 3 , at 5 . 
terminants of voters' views toward public welfare programs. As Gilens reports, "the desire to save taxpayer dollars consistently emerges as a low priority in the public's thinking about welfare reform." ${ }^{2}$ Although a small number of respondents point to cutting costs as the most important goal of welfare reform, most would be willing to pay higher taxes for programs that help welfare recipients help themselves. ${ }^{53}$ Moreover, support for welfare programs does not abate when times are hard, but is strongest when the economy sours and the burden on taxpayers is greatest. The best explanation for this pattern is that voter preferences in this area are not primarily a function of what programs cost and whether taxpayers see themselves as benefiting directly. Rather, the popularity of poor relief waxes with the perception that many poor are victims of circumstance, and wanes when the poor are believed to have ample opportunities to better themselves. As Gilens suggests, these patterns are consistent with a "small role [for] economic self-interest in explaining opposition to welfare spending," ${ }^{54}$ and a large role for beliefs about fairness and reciprocal obligation.

These observations also help explain why cheap welfare programs such as Aid for Families with Dependent Children ("AFDC") are unpopular, while expensive programs like Social Security, which consumes a large chunk of the federal budget, are favorites of the voting public. Although the wider dissemination of benefits under the Old Age program may account for some of this difference, another explanation is that AFDC, but not Social Security, is viewed as violating reciprocity norms that most voters accept. There is ample evidence that these norms exert an important influence apart from voters' perceptions of the costs of these programs to them or to persons like them. ${ }^{55}$

52. Id. at 192 .

53. See id. at $187-88,192$.

54. Id. at 192.

55. Voters may also oppose federal anti-poverty programs from a fear that the programs promote deviant behaviors, including idleness, dependency, drug use, crime, and out-of-wedlock childbearing. If voters perceive these behaviors as imposing costs on themselves, their opposition will, to that extent, reflect self-interest. Most certainly, the assertion that welfare causes poverty, social pathology, and family breakdown is highly contested, and it is difficult to know whether these fears are a more important source of opposition to welfare than moralistic indignation against perceived free-riding and "taking advantage." This suggests that, in shaping political outlooks on welfare, "irrational" concerns with fairness and reciprocity dominate more "rational" factors, such as actuarially sound calculations of expected risks of future destitution and costs of supporting others.

Another factor that may help explain the pattern of support for different programs is that, contrary to a core assumption of the mutual insurance game, see generally SUGDEN, supra note 20, not all voters are equally at risk of falling into poverty. This minimizes the insurance payoff for them, and leaves more room for selfish motives. Nonetheless, the data suggests that voters' views are only minimally responsive to this differential in risk. The preoccupation in voter surveys with fairness and reciprocity concerns does not vary significantly with social class, and the well-to-do are not less supportive of welfare reform than welfare recipients themselves. See, e.g., FARKAS ET AL., supra, note 3, at 44-47 (comparing views of the general public and welfare recipients). This suggests that "irrational" concerns with fairness and reciprocity dominate more "rational" factors, such as actuarially sound calculations of expected risks of future destitution and costs of supporting others, in shaping political outlooks on welfare.

Yet another factor grounded in self-interest that may help account for popular support for public welfare may be the perception that distributing resources to the least well-off ameliorates negative externalities generated by a large destitute population. See Lee Anne Fennell, Interdependence and 
To summarize, the pattern of attitudes toward public welfare programs is not best explained by voters' narrow calculations of self-interest. Rather, the notion that normative expectations regarding dependency dominate voters' views provides a better account. Adherence to those norms can arguably be explained as the application of attitudes that were essential to maintaining collective forms of sharing throughout human history. Although features of modern welfare programs diverge in important respects from collective, voluntary mutual aid arrangements, elements common to all schemes of mutual support and redistribution of resources-elements shared by informal cooperatives as well as complex modern welfare programs - may tap into attitudes forged in a more primitive era. The impulses of generosity toward the faultlessly helpless, and of stinginess toward the willfully needy, may stem from a period when such sentiments were adaptive in facilitating the emergence of stable arrangements for reciprocal assistance. Whether as a matter of cultural or biological evolution, norms consistent with these impulses can be expected to exert some control over our responses today.

VI

\section{WELFARE REFORM: THE TRIUMPH OF ORDINARY POLITICS?}

This account helps make sense of the longstanding public dissatisfaction with the design of federal relief for the poor and the current popularity of Clinton's PRA legislation. The data suggests that a majority of voters favor collective responsibility for the poor and want to help the poor become economically independent. They are reluctant, however, to support needy persons who show little interest in supporting themselves. Because an important route to self-sufficiency is work, the public can be expected to favor policies that encourage or require able-bodied persons to engage in paid labor or to ally themselves with someone who does. ${ }^{56}$ Moreover, as Gilens suggests, dissatisfaction with existing policies and support for reform correlate with the perception that many beneficiaries are "taking advantage of the system" by doing too little for themselves. All of these observations help explain the popularity of President Clinton's initiative.

Choice in Distributive Justice: The Welfare Conundrum, 1994 U. WIS. L. REV. 235, 267-69, 274-76 (using game-theoretic models to argue that welfare programs are not a zero-sum game and that collective benefits from these programs in modern societies are potentially felt at all levels). $C f$. DONALD F. NORRIS \& LYKe THOMPSON, THE POLITICS OF WeLFARE REFORM 11 (1995) (describing the politics of redistribution, because it involves "taking resources away from one group and giving them to others," as inherently "conflictual" and as pitting "one section of the community against another"). The belief that anti-poverty measures generate modest collective gains may help fuel public support for government welfare programs, even to the point of overriding a commitment to the deserving and undeserving distinction. For example, a belief that poverty encourages crime may make voters more willing to provide money to the poor regardless of self-help potential, on the theory that resources reduce the temptation to break the law even among the able-bodied poor.

56. See discussion infra notes 60-76 (comparing attitudes toward married homemakers and unmarried mothers on welfare). 
The AFDC program, which has been the mainstay of federal relief for the poor since the New Deal, initially embodied expectations consistent with strong reciprocity, but only in light of customs, understandings, and social practices prevailing at the time of enactment. Because the program was confined to single parents with children, it denied benefits to most able-bodied men. The expectation that able-bodied women would work was not part of the program's design at its inception. On the contrary, the program implemented the understanding that single mothers should personally care for their children, which required them to depend on public support. Twenty-five years after the enactment of the AFDC legislation, however, the consensus that single mothers should depend on the government began to fade as more mothers started to work and the number of out-of wedlock births exploded. Beginning in the 1960s, Congress revised the authorizing legislation to incorporate work incentives and programs. Until the 1980s, these were mostly voluntary and were only sporadically implemented. ${ }^{57}$ Even under the Reagan Administration, and despite decisive changes in popular attitudes toward mothers in the labor markets, formal self-help requirements under AFDC remained weak. ${ }^{58}$ Dissatisfaction with AFDC grew as changing mores fueled the perception that many mothers were violating the unwritten conditions of strong self-help. ${ }^{59}$ This led to sustained calls for more stringent rules of eligibility, including serious enforcement of work requirements and time limits on benefits. In keeping with voters' views, reformers recommended a shift in emphasis from cash benefits to programs that facilitate employment, including child care and transportation subsidies, training, child support, and other work-related services. All of these features have found their way into the new welfare reform package.

Popular acceptance of basic norms of reciprocity can also help explain the apparent paradox of widespread support for work requirements for single mothers on welfare, coupled with the general approval (or at least lack of disapproval) of married mothers' staying home to care for their own children. It is sometimes claimed that public condemnation of single mothers" "dependency" on the government is inconsistent with applauding married mothers" "depend-

57. See LAWRENCE MEAD, BEyOND ENTITLEMENT 149-56 (1986) (explaining administration of the JOBS and WIN programs); Lawrence Mead, Welfare Employment, in THE NEW PATERNALISM: SUPERVISORY APPROACHES TO POVERTY 39 (Lawrence M. Mead ed., 1997) (same); see also, e.g., J. L. Mashaw, Welfare Reform and Local Administration of Aid to Families with Dependent Children in Virginia, 57 VA. L. REV. 818 (1971) (detailing broad variation in administration of AFDC in different counties in Virginia during the 1970s).

58. See FARKAS ET AL., supra note 3, at 21-22 (describing strong support for paid employment for welfare mothers); GILENS, supra note 3, at 178-87 (describing changing norms surrounding mothers working; and introduction of work programs for AFDC).

59. As already suggested, see supra note 55, growing opposition to support for single mothers may also have stemmed from the belief that AFDC hurts the very people it is designed to help, or that it encourages out-of-wedlock childbearing, discourages marriage and male responsibility, and indirectly fosters lawlessness and crime. See, e.g., Charles Murray, Losing Ground: American Social POLICY (1984); MEAD, BEYOND ENTITLEMENT, supra note 57, at 149-56. 
ency" on breadwinner husbands. ${ }^{60}$ Our analysis suggests, however, why the public might view these two forms of dependency very differently. What offends the norm of reciprocity is not the dependency (or interdependency) of individuals on one another as such, but rather attempts by private individuals or entities to call upon collective resources willfully or without necessity. Indeed, within the mutual aid context, the "dependency" of individual family members on one another is of no practical concern to the broader collective overall, so long as the family arrangement is consensual and mutually agreeable and the smaller social unit "pays its way." But most families consisting of mothers with employed spouses do indeed pay their own way. Considered as a unit, breadwinner-homemaker families, and two-parent families generally, are almost always self-supporting and able to live decently without public subsidy. Most contribute to common assets through taxes and may also generate other forms of social value. ${ }^{1}$ Because these types of families almost always function as donors rather than recipients for purposes of public subsidies, they are generally regarded as living up to expectations. Most do not break with the demands of strong reciprocity because they rarely need to draw from the common pot at all, let alone for impermissible reasons.

What of traditional breadwinner-homemaker families that cannot manage to support themselves? Although unusual, such "working poor" families do exist. ${ }^{62}$ Some of these families, which include but are not confined to breadwinner-homemaker units, pay little or no taxes or actually receive a net subsidy within our system through programs such as the Earned Income Tax Credit. ${ }^{63}$ These subsidies are not necessarily inconsistent with an adherence to strong reciprocity within the mutual aid paradigm, however. Families in which one or more members work reasonably hard in the paid labor market thereby demonstrate their willingness to help themselves. They make a good faith effort to function as a net contributor to collective resources maintained for mutual secu-

60. See, e.g., SCHMIDTZ \& G 
rity, which is all that strong reciprocity requires. If economic reality is such that this effort does not suffice to achieve self-support for the unit or to generate a surplus for the group, the family does not thereby show itself to be "undeserving." On the contrary, the inability to achieve donor status within the game despite best efforts is precisely the situation that establishes desert and permits players to accede to the status of recipients of group resources. Players in the mutual aid game are entitled to draw on collective help only if they are in need for reasons beyond their control. Many of the working poor arguably meet this description. ${ }^{64}$

Single mothers' dependency on government aid presents a different story. The parallel between married mothers' dependency on their husbands' earnings and single mothers' dependency on government programs is often put forward to justify public assistance for the latter without any requirement that they engage in paid work at all. The contention is, in effect, that single mothers, by virtue of their mothering function, should have an unconditional right to full public support. By definition, then, these mothers function as recipients rather than as donors in the mutual aid game. Under strong reciprocity, this would immediately trigger an inquiry into whether they could do more to help themselves. For many single mothers, the answer would appear to be yes: They could go to work and earn something, even if not quite enough to live on. Their earnings would at least offset some of the draw on public funds.

As already suggested, however, matters are not quite so simple. The case of single mothers with children is considerably complicated by cultural norms regarding what mothers can reasonably be expected to do, whether mothers belong at home, and whether having children out-of-wedlock is immoral or devi-

64. There is indeed some dispute about whether this picture of the "working poor" is accurate. The key requirement for desert within the mutual aid game is that the effort toward self-sufficiency must be a reasonable one. That perception is strongly influenced by conventional expectations about how hard and long families and their members are expected to work on the market, as well as by views about the opportunities actually available to low-skilled workers to increase hours of work and income. Many commentators have argued that one unskilled person, especially if that person is a woman, cannot support a household of average size under current economic and labor market conditions. See, e.g., KATHRYN EDIN \& CHRISTOPHER JENCKS, RETHINKING SOCIAL POLICY 204-08, 221-25 (1992); KATHRYN EDIN \& LAURA LEIN, MAKING ENDS MEET (1997). Those who reject this conclusion note that men earn more than women and that "two heads are better than one." They recommend marriage as one solution to the low earning power of mother-only families. See, e.g., Lawrence Mead, Low Wages and Hard Times, in THE NEW POLITICS OF POVERTY (1992); see also Murray, supra note 59. Compare Kathryn Edin, Few Good Men: Why Poor Mothers Stay Single, AM. Prospect 26-31 (Jan. 3, 2000) (arguing that poor women's failure to achieve family self-sufficiency by marrying cannot be regarded as a "voluntary" choice).

Lawrence Mead, among others, also marshals evidence that poverty among families with at least one worker often results from the voluntary decision by able-bodied family members to work less than full time or year round. In other words, there is room for the working poor to do more to help themselves. Mead holds up the model of recent immigrants, in which multiple family members work long hours at low wages to put together a decent family income that allows them to "get ahead." For a similar view, see, e.g., Bradley Schiller, Who are the Working Poor?, PUB. INT. 65-69 (Spring 1994) (noting evidence that poverty among families with at least one worker is due to the voluntary choice of family members to work less than full time and year round, and not to structural unemployment or low wages). 
ant. ${ }^{65}$ Fairness-based critiques of public aid for single mothers must also confront the claim that although single mothers on welfare may not have market earnings, they perform the valuable work of raising children and thereby making a substantial (and adequate) contribution to social welfare. In the currency of the mutual aid game, this suggests that rearing children ought to count as a reasonably sufficient contribution or noncash "donation" to the common pot, which triggers a quid-pro-quo entitlement to public help. Put another way, the contention is that mothers, simply by functioning as mothers, have done "enough" to satisfy fairness and reciprocity requirements.

Should it matter for purposes of satisfying the requirement of strong reciprocity that raising children is, in some sense, "work"? Childrearing certainly requires an expenditure of effort. It also generates benefits of various kinds, including, perhaps, "public goods" or positive externalities from the production of good citizens. These are benefits in which the wider public can potentially share. ${ }^{66}$ Yet the creation of these forms of value, and the expenditure of effort that produces them, does not in itself establish entitlement to full public support if strong reciprocity norms are taken seriously. Even if a single mother can be said to "donate" some resources to the collective, most of her efforts go toward her own (and the father's) "consumption value" in having and rearing the child, or toward conferring an altruistic gift of care on the child itself. These are purely private benefits, for which the collective is being asked to pay. Whether the private gains that mothers and children enjoy at public expense exceed any public benefit, such that the balance of costs and benefits is negative for the collective, is difficult to determine. However, because private "consumption" and investment value would appear to loom large for each individual mother and child compared with any externalized benefits to others, it seems unlikely that the collective would come out ahead overall from underwriting the support for all single women with children who choose to avail themselves of help. ${ }^{67}$ The impression of net cost is exacerbated by certain negative externalities attributed to single motherhood as a social practice. ${ }^{68}$ There is some evidence that single mothers, especially among the poor and poorly educated, produce a dispropor-

65. See note 36, supra.

66. See Amy L. Wax, Is There A Caring Crisis? A Review of Shirley Burggraf's The Feminine Economy and Economic Man, 16 YALE J. REG. 327 (Summer 1999) [hereinafter Wax, A Caring Crisis] (discussing externalities theory); Amy L. Wax, Caring Enough: Sex Roles, Work, and Taxing Women, 44 VILL. L. REV. 495 (1999) (same); see also Paula England \& Nancy Folbre, Who Should Pay for the Kids?, 563 Annals AM. ACAD. POL. \& Soc. SCI. 194 (May 1999).

67. The very existence of positive externalities from child-rearing may provide a compelling reason to offer some kind of universal public subsidy for families with children. See, e.g., Wax, A Caring Crisis, supra note 66; Wax, Caring Enough, supra note 66. How large the subsidy should be and whether it should vary with a woman's economic circumstances and labor value is hard to say. That the element of fair and efficiency-enhancing compensation for positive externalities is difficult to disentangle from the component of private subsidy may help explain the strong reluctance to offer a substantial acrossthe-board public benefit for families with children as well as the unpopularity of programs that carry the full freight for needy single mothers.

68. There is reason to believe that private gains, specifically to fathers, are also reduced in the outof-wedlock situation. See, e.g., Robert J. Willis, A Theory of Out-of-Wedlock Childbearing, 107 J. POL. ECON. S33 (1999). 
tionate number of dysfunctional children. ${ }^{69}$ This fosters the view that support for single mothers comes at society's expense. The analysis suggests that a belief that unconditional public assistance for single mothers violates norms of reciprocity begins with a perception that welfare mothers and their families give back to society less than they receive.

But the perception that single parent families are a net drain on collective resources is not the end of the story. As we have seen, an imbalance between individual contribution and public support does not pose a problem for strong reciprocity if the individual who calls upon group support is unable to improve upon the situation or to reduce her need for public funds. If the net balance is beyond her control or not her own fault, public subsidies will not elicit resentment and will generally be forthcoming. But whether the neediness of many poor single mothers is in some sense "involuntary" is a hotly contested question that, for many voters, yields a negative answer. In considering whether single mothers "deserve" public support, the public is asked to determine whether each step on the road that so often leads to public dependency-lack of educational success, drug use, failure to marry, unprotected sexual intercourse, pregnancy, giving birth and keeping the child, failure to seek or retain employment-can be regarded as within an individuals' meaningful control and thus one for which the would-be recipient can properly be held responsible. How should these decisions be situated on the continuum from choice to luck, and how should they count in establishing a person's status as "defector" or "cooperator" in the game? The answers to these questions necessarily depend on empirical facts as well as normative judgments. To add to the complication, neediness among single mothers often results from past decisions with present irrevocable consequences. Whereas someone could have avoided their current dilemma, there may now be little they can do to improve the situation or engage in meaningful self-help. One question that consistently arises in the application of the strong reciprocity norm is whether persons will be held strictly accountable for past imprudence, or will be viewed as "deserving" because future efforts are bound to prove largely unavailing. There is some uncertainty over how to answer this question and evidence of a recent shift towards the more lenient forward-looking standard..$^{70}$

69. See, e.g., Sara S. McLanahan, The Consequences of Nonmarital Childbearing for Women, Children, and Society, in DePARTMENT OF HEALTH AND HuMAN SERVICES, REPORT TO CONGRESS ON OUT-OF-WEDLOCK CHILDBEARING 229, 231-33 (Sept. 1995) (presenting data on outcomes for children in single-parent families); Andrew Cherlin, Going to Extremes: Family Structure, Children's Wellbeing, and Social Science, 36 DEMOGRAPHY 421-28 (Nov. 1999) (same).

70. The new welfare reform regime appears to have adopted the weaker version of the strong reciprocity requirement in this regard. As with the old AFDC statute, support for single parents is provided, albeit for a limited period, regardless of the reason for need. Continued assistance turns on the present willingness and ability to take steps towards independence and little effort is made to determine whether past choices have led to greater or more prolonged need in the present. This forward-looking emphasis may be motivated by the view that resources are better expended on aiding present self-help efforts than on conducting cumbersome investigations of past roots of present predicaments. 
Although the analysis here does not resolve all of these issues, it does help explain why mothers will not necessarily be considered "deserving" of full collective support under strong reciprocity by virtue simply of their status as mothers. $^{71}$ The central inquiry in applying the reciprocity condition in the allocation of collective resources is always to what extent a player's use of, or contribution to, the common resource is a matter of choice or a matter of circumstances beyond that person's control. Help is withheld to the extent need is seen as the product of some present volitional act, and help will be forthcoming to the extent need is unavoidable. The critical factor, then, is not whether a player can be said to perform "work," in the sense of expending costly effort of some kind, as mothers undeniably do. Nor does it suffice that the effort expended results in some benefits flowing to the collective, as the work of mothering arguably does. Rather, the question appears to be whether a given player, despite both effort and contribution, can reasonably be expected to do more to achieve selfsufficiency, and, if possible, to contribute to the social surplus. The suspicion that the expectation has not been met is heightened when the individual, despite some exertion, is still "needy"-so that the net flow of resources is away from the group and toward the individual. In that case, the collective is bound to consider closely whether the imbalance of payments is a matter of luck or choice. Is it within the power of the player to reverse the flow or reduce itthat is, to become a donor rather than a recipient, or at least to donate more? If the answer is "yes," then the contribution made and the effort expended will be considered insufficient. As already noted, the answer is necessarily informed to some extent by cultural expectations. Social norms and opinions differ on what people, including mothers, can reasonably be expected to do on their own behalf. In addition, it is unavoidable that conventional notions about human volition and the role of external social forces will inform the identification of life decisions for which people can properly be held responsible. But within the limits marked out for accountability, the inquiry triggered by the quest for public assistance comes down to this: Has this person tried hard enough to help himself? If the proper effort has been made, help will be supplied regardless of the effectiveness of the effort. If the effort is inadequate, help will be withdrawn or denied.

This discussion of mothers' work helps explain why supporters of generous benefits for single mothers take pains to emphasize the degree to which these women's predicament must in some sense be considered involuntary, or why poor women cannot reasonably be expected to control their fertility, marry, and work. It also sheds light on a key point of confusion that plagues discussions of reciprocity norms in many social contexts. The issue is often framed as one of deciding how much and what kind of work counts as a "contribution" that suffices to satisfy the prevailing standard of fair reciprocity and entitles a person to

71. See, e.g., sources cited supra note 66. 
collective assistance. ${ }^{72}$ That determination would seem fairly straightforward for the absolutely indolent, for those who "lie in bed all day and drink beer all night." " 33 Yet very few people, even if not in the paid workforce, are completely idle or totally "unproductive," and many individuals could arguably work harder or earn more. ${ }^{74}$ The requirements of strong reciprocity in playing the mutual aid game would appear to provide some guidance on the question of "how much is enough" by supplying a criterion for when individuals satisfy the requirements for a "member in good standing" within the game. Generalizing from the discussion of public support for single mothers, the critical insight boils down to this: Not every productive or effortful activity counts as adequate to establish cooperative conduct under the rules. The key factor is whether the individual is able to do more to support himself and contribute to the collective and can reasonably be expected to exert that additional effort. ${ }^{75}$ The determination of whether someone has done "enough" or should do more has an unavoidably conventional component: It is subject to a rule of reason and prevailing customary norms which are partly a function of economic conditions. That determination is not left to individual whim, however.

If the person is deemed to have done enough to help himself and is still in need, he stands to qualify as a recipient despite the modesty of his actual input. The group effectively commits itself to bringing him up to some baseline minimal standard of living by "making up the difference" between what he can

72. See Folbre, supra note 60 , at 21 (noting the puzzle of what counts as a reciprocal relationship, given that some quite unequal exchanges are regarded as fair swaps whereas others are not); White, supra note 37, at 22-23 (asking "how, at any given time, can we make a non-arbitrary distinction between forms of work that count as productive contributions from the standpoint of reciprocity principles and forms of work which do not count as contributive in this way"). For additional discussion of the conundrums surrounding the definition and measurement of "work" and social contribution, see Wax, Something for Nothing, supra note 18.

73. Joseph H. Carens, Rights and Duties in an Egalitarian Society, 14 POL. THEORY 31, 36 (1986).

74. On this, see Randy Cohen, The Ethicist: A Free Ride, NY TIMES MAG., Oct. 31, 1999, at 30 (letter from reader questioning the ethics of an "underemployed" neighbor's daughter receiving needbased college financial aid).

75. How do the "idle rich" fit into this picture? In short, the rich play by the rules of strong reciprocity because they contribute to the common fund (through taxes) and do not ask to receive. By definition, they do not qualify as "undeserving" because they fail to satisfy the predicate for lack of desert within this context. They do not seek any support at all from the collective, let alone for the wrong reason, and they cooperate by contributing resources to the common pot when they are supposed to.

Accordingly, one would not expect the idle rich to arouse as much ire as the idle poor. But that does not mean they come in for no disapproval at all. Those who live a life of leisure on inherited wealth, for example, would in some sense be regarded as "undeserving." The notion of desert is far broader than the concept that does service in the specialized context of strong reciprocity within the mutual aid arrangement. In modern liberal societies, persons are generally thought "deserving" of wealth and rewards only by dint of some kind of personal effort, contribution, achievement, or accomplishment. See, e.g., Miller, supra note 48, at 131-55; GEORGE SHER, DESERT (1987). Past effort counts, and the privilege of retiring on earnings from an earlier stage of life is generally well accepted. But the individual himself must have expended some kind of effort at some time. Although some of the idle rich may transgress that broader norm, it does not follow that they are "undeserving" for purposes of participating in a mutual aid scheme for which "desert" is a term of art that relates to satisfying the conditions for receiving help from the common pot by lending the requisite support to the collective. Legal rules that sanction inherited wealth make it possible for a person to do his duty by these lights even with money he has not himself earned. 
achieve for himself and the level of well-being that the group has pledged to guarantee. (Indeed, the assurance that all who do their best to contribute will at least not starve is the whole raison d'etre behind the mutual aid arrangement.) If the person has not done enough to help himself, he will not receive additional help to raise his standard of living to the guaranteed baseline. Through his lack of cooperation, he disqualifies himself as a recipient of aid and is thrown back on his own devices. In sum, the mere fact of positive contribution is not enough. The contribution has to be sufficient under some normative convention established by reference to common practice and other factors to qualify as a cooperative effort within the game. Conversely, the convention would appear to entail a strong commitment to help the so-called "working poor" achieve a minimally decent standard of living. Indeed, the reciprocity norm points decisively in the direction of policy measures that support workincluding tax relief, wage subsidies, and in-kind benefits for the working population-even when the cost of these supports exceeds the overall gains from putting people to work. A strong reciprocity norm within a mutual aid paradigm is fully consistent with — and arguably mandates — a social pledge to keep all fulltime job holders above the poverty line regardless of workers' actual productive capacity. ${ }^{76}$

\section{VII}

\section{Welfare Politics, Reactive Attitudes, And Opposition to Welfare}

The account of welfare politics offered here, as well as recent real-life experience with the PRA, offer a challenge to conservative critics of the welfare state. Conservative opposition to public welfare programs rests on several grounds. These include a libertarian hostility to coerced property transfers that are imposed on individuals by the majority. Because transfers should be left up to individual choice, private charity and voluntary self-help organizations are the preferred means of poor relief. Also important are concerns with the inefficient waste of resources. The absence of individual consent in government transfer programs invites rent-seeking through interest-group politics. An important part of conservative opposition to public welfare has nothing to do with freedom or efficiency, however. It stems from the belief that government policies in aid of the poor will inevitably gravitate toward static rather than dynamic notions of need. The fear is that government welfare programs are destined to deviate from basic rules of reciprocity and fairness-rules that many who are skeptical of public welfare invest with moral significance. ${ }^{77}$

76. Of course, lines must be drawn about what kinds of full-time work will qualify for public subsidy. Workers may earn less than subsistence wage on the market because they are unskilled or because they choose to do pleasant work for which there is little demand. Should the state undertake to make up the difference for full-time artists, for example, who have no hope of making a living on their own? Any system that seeks to guarantee baseline well-being for all who work must confront these dilemmas, including the questions of how much leeway skilled individuals should have to choose the kinds of work they want to do. See note 97, infra.

77. See e.g., KELLEY, supra note 13, at 101-17. 
The prediction is grounded partly in the view that government programs tend to be overly rigid and bureaucratic. Governments find it difficult to make distinctions based on factors going to desert, including effort, ability, behavior, and individual circumstance. Sufficiently individualized information is difficult to obtain, and anti-discrimination rules and rule-of-law norms bar governments from acting on the sorts of judgments that a strong reciprocity rule requires. Governments are also held to standards of justification that make fine distinctions difficult to verify and defend. ${ }^{78}$ Finally, bureaucrats have no incentive to apply strict rules, as the money they spend is not their own. All of these factors tend to push governments toward formal and informal application of a static, rather than a dynamic, conception of need. That is, the tendency is to offer help to those lacking resources, regardless of the potential for self-help.

The problem with this view is that it ignores the reality of welfare politics and the psychology behind that reality. Critics of government-run welfare programs fail to appreciate that widespread assent to reciprocity norms provide a built-in safeguard against the maintenance of programs that disregard conventional notions of responsibility. Public opinion is not likely to tolerate practices that remain permissive for too long.

The historical evidence is consistent with this view. As noted, the distinction between those expected to work (and thus "undeserving" of support) and those who are not expected to work (and thus "deserving" of assistance) has always been a central feature of public welfare schemes in this country. What has changed, and indeed varies considerably over time, is not the use of these categories, but the scope assigned to them. Recent innovations in federal welfare programs express an evolving public judgment that single mothers, who previously were thought to be an appropriate public charge, are instead free-riding on the rest of us and must now be classified among the able-bodied. The new welfare law uses work requirements and time limits as (quite imperfect) operational devices to distinguish those now regarded as capable of self-help from those who are not expected to contribute to the social surplus through market work. $^{79}$

78. It is also claimed that the very requirement that statutory or regulatory conditions be adhered to by the government without exception, regardless of their content, breeds a sense of entitlement. That mentality is said to foster dependency, which generates more substantial claims on public largesse. See id. at 105 (quoting a 19th-century clergyman, who observed that "[t]he state, as the institute of rights, can give nothing to any man without conceding that it is his right to have it.... Every dollar it spends on the relief of the poor, is an admission that they have the right to be supported at the public expense.").

79. The existence of state and federal benefits for the unemployed medically disabled reflect a social judgment that persons with medical conditions of sufficient severity are not expected to work at all and "deserve" full support at public expense. Whether it is strictly consistent with a norm of reciprocity to relieve many of the medically disabled of the obligation to expend at least some effort toward selfsupport even short of self-sufficiency is a nice question that is beyond the scope of this paper. It is worth observing, however, that the current social welfare regime would appear to embody the expectation that persons with low ability or poor skills-who are also unlikely to achieve self-sufficiency under current economic conditions-must participate in the paid economy, even if society ends up providing extra resources through in-kind benefits, income or wage subsidies, tax subsidies, and the like, to bring them up to a decent standard of living. The more generous treatment of the disabled as compared to 
Recent experience with putting welfare reform into practice also suggests that government programs can mimic some of the virtues attributed to private poor relief efforts. The block-grant structure has given states and localities broad authority to adopt stricter rules for work and eligibility and has also conferred wide discretion to devise programs to support recipients' self-help efforts. These include job training, work-support and counseling, childcare, transportation assistance, and short-term loans. The evidence so far suggests that state and local bureaucracies have used their authority to impose demanding conditions on welfare recipients and have followed up with real sanctions for violations. ${ }^{80}$ In addition, local government agencies have made use of the flexibility and autonomy conferred by the block-grant design to help recipients in novel ways and to forge partnerships with private organizations experienced in preparing recipients for work and supporting their efforts. ${ }^{81}$ Many of these programs rely on close, personal relationships between clients and caseworkers. Workers supervise, monitor, encourage, guide, and admonish welfare recipients, establishing bonds that are typical of private charitable or self-help groups. $^{82}$ Using these methods, welfare-to-work programs have scored significant successes in moving former recipients into the workforce, cutting the welfare roles, and getting people to avoid welfare in the first place. ${ }^{83}$

These developments suggest that governments are capable of enforcing the types of stringent conditions that comport with reciprocity norms and can take a flexible approach to making those conditions work. The conservative perception that state public welfare programs are doomed to the twin hazards of leniency and rigidity may be the product of accident, not essence: In the middle part of this century, many welfare bureaucracies were captured by left-leaning ideological factions that did not share the views of voting majorities. The chronic under-funding that rendered work programs ineffective fueled the per-

the "poorly abled" may reflect not so much the dictates of consistency as a pragmatic response to the lesser moral hazard created by excusing those with a verifiable medical condition.

80. See, e.g., GAO REPORT, supra note 1; HHS REPORT, supra note 1, at 34-47 (documenting the drop in rolls and the transition of former welfare recipients to employment).

81. See, e.g., Michael Grunwald, How She Got a Job, AM. PROSPECT 25 (July-Aug. 1997) (describing government contractual arrangements with private "One With One" training and placement program as authorized by welfare reform legislation); Kay Hymowitz, At Last, a Job Program that Works, CITY J. 32 (Winter 1997) (describing "Strive" employment training and placement program); Donald K. Jonas, Business of Welfare Reform a Success In Florida, ORLANDO SENTINEL, Oct. 6, 1999, at A13 (describing role private businesses have played in Florida's welfare reform efforts); see also Sharon Hays, Inside Welfare: Gender, Family Values, and the Work Ethic, Presentation to the Program on Children, Families, and Law, University of Virginia (Fall 1999) (reporting on fieldwork documenting local welfare office practices under the Temporary Assistance for Needy Families ("TANF") program of providing discretionary payments for car repairs, car loans, dental work, childcare, moving expenses, and other work-related needs).

82. See, e.g., Jason DeParle, For Caseworker, Helping is a Frustrating Struggle: Life After Welfare: The Caseworker, N.Y. TIMES, Dec. 10, 1999, at A1; see also HHS REPORT, supra note 1, at 202 (describing flexible, hands-on approach of various state welfare-to-work programs and demonstration projects under welfare reform).

83. See references cited in note 81 , supra. 
ception that such programs are doomed to failure. The progress of welfare reform so far shows that this perception is almost certainly wrong.

The success achieved by local agencies in making use of the autonomy conferred by the new welfare reform legislation suggests that the system is capable of exercising a considerable degree of discretion, and that the public will accept discretionary authority that is used to advance reciprocity-based objectives and is not obviously abused. A public welfare regime also need not invariably breed an entitlement mentality. The belief that cash welfare benefits will be automatically forthcoming for indefinite periods and without strings appears to be fading fast among the welfare population. The dramatic decline in welfare rolls may in part be attributable to a heightened understanding among single mothers themselves - the principal group that previously qualified for federal poor relief - that the public no longer views them as entitled to public support, at least not without a substantial reciprocal effort on their part. Perhaps potential welfare recipients are finally getting the message that they are expected to do everything they can to lift themselves out of poverty, which includes entering the workforce, forswearing drugs and crime, and avoiding potentially costly childbearing.

Although the evidence suggests that welfare reform has so far managed to avoid many of the vices attributed to government welfare programs, welfare reform has not wholly wiped out the agency costs inherent in the administration of welfare policies. There remains a considerable temptation for bureaucrats to be lenient, rather than exacting, in formulating and applying rules, because strictness requires effort, and there is little downside to spending other people's money. ${ }^{84}$ However, these incentives are not the only factors at work and need not dominate. Countervailing sentiments can temper these tendencies under the proper conditions. Like voters-at-large, welfare administrators need not be motivated by narrow self-interest alone. An important part of welfare reform is to give responsibility to officials who share most voters' views of self-support as a paramount value, or to persuade existing personnel to that view. Another is to adopt administrative practices that make welfare reform more effective. As Lawrence Mead has shown, bureaucrats' self-interest and beliefs about the value of work are not the only factors bearing on the administration of program requirements. Significant variations in the effectiveness, efficiency, and conscientiousness of low-level welfare bureaucracies turn on mundane details such as fund management, clear prioritization, and organizational acumen. ${ }^{85}$

84. Public workfare programs, especially, are plagued with thorny problems of administration that may never be entirely solved. See Matthew Diller, Working Without a Job: The Social Messages of the New Workfare, 9 STAN. L. \& POL'Y REV. 19 (1999).

85. See MEAD, BEyOND ENTITLEMENT, supra note 57, at 149-56 (detailing types of bureaucracies that are most successful in moving beneficiaries from welfare to work); Mead, Welfare Employment, supra note 57, at 39; see also J. L. Mashaw, Welfare Reform and Local Administration of Aid to Families with Dependent Children in Virginia, 57 VA. L. REV. 818 (1971) (detailing broad variation in administration of AFDC in different counties in Virginia during the 1970s). 
In sum, the view that public welfare is all bad and private poor support all good is based on too-narrow a picture of welfare politics and administration. The line between the psychology of informal group cooperation and the political psychology of state-sanctioned redistribution is not as sharp as critics of welfare make out. The common attitudes triggered by demands for group support in both settings serve as a hedge against maintaining a system that fosters runaway dependency or an unconditional sense of entitlement.

In addition to calling into question the position of anti-welfare conservatives, this analysis offers comfort to liberal supporters of public welfare programs. The politics of welfare, although perhaps inevitably informed by certain large themes, varies with circumstances. Furthermore, it is important to remember that what has been enacted into law can be revised at any time. The push for reform was prompted by the belief that welfare recipients really could do more for themselves, but this perception is subject to change as reform runs its course. In the initial stages of reform, strict work requirements and time limits succeeded in shrinking the rolls by encouraging the most able and least troubled welfare recipients to wean themselves from public support. However, as Robert Goodin notes, the reformist policies that work so well at first may eventually "end up penalizing the deserving as well as the undeserving poor." ${ }^{\prime 6}$ He notes that "ironically, the harsher [the] deterrents [to remaining on the welfare rolls] - the more they succeed in deterring those who have it within their power to avoid them-the more those who are left suffering their penalties are those who do not in any way deserve them." 87 As welfare reform progresses, only the hard-core cases are left on the rolls. Fewer and fewer of the remaining recipients can, in any realistic sense, do much more to help themselves.

The work requirements of the Temporary Assistance for Needy Families Act ("TANF") program are now being implemented in a booming economy and the five-year federal lifetime limit on TANF cash assistance has not yet expired in many states. The reformist zeal behind TANF may eventually run up against two brute facts of economic life: structural unemployment and low productivity. There are simply not enough jobs to go around, even in the best of times. Poor skills and intractable behavioral problems mean that the costs of employing at least some welfare recipients may end up outweighing the benefits, even at minimum or "workfare" wages. ${ }^{88}$ Therefore, a few welfare recipients will never be able to hold down private sector jobs, and many of those will have trouble holding public jobs as well. Although the TANF statute permits states to exempt up to twenty percent of recipients from work requirements, ${ }^{89}$

86. SCHMIDTZ \& GOODIN, supra note 15 , at 177.

87. $I d$.

88. See, e.g., EDMUND PHELPS, MAKING WORK PAY (1997) (describing workers who are not worth even minimum wage); see also Hymowitz, supra note 81 (discussing work as a condition of public support for low productivity workers).

89. See BLOOM, supra note 3, at 92. States have made variable use of the option to exempt up to one-fifth of the welfare population from work requirements. See HHS REPORT, supra note 1, at 171- 
not all states have taken full advantage of that safety-valve provision. And although states may also, within specified limits, exempt up to one-fifth of recipients from the five-year lifetime limits for benefits, the least employable population may still suffer hardships as that deadline approaches in many states, especially if the economy slows. As it proves increasingly difficult to locate unsuccessful welfare recipients on the deserving/undeserving axis, public support for time limits may erode or pressure may build to further expand exceptions to work requirements. $^{90}$ The public may also come to realize that true self-support for the low-skilled requires full-time work, which most people are reluctant to impose on mothers of very small children. ${ }^{91}$ Finally, voters generally believe that children cannot be "undeserving" and should not suffer egregiously from their parents' irresponsibility. ${ }^{92}$ If it becomes apparent that children are being

81; see also Christopher Jencks \& Joseph Swingle, Without a Net: Whom the New Welfare Law Helps and Hurts, AM. PROSPECT, Jan. 2000, at 37, 40-41.

90. Persons out of work due to structural unemployment, low skills, or poor work habits do not qualify for federal disability benefits under programs as currently structured. See note 79, supra. Behavioral problems that make it difficult to hold a job may occasionally be attributed to psychiatric conditions that are classified as disabilities, but some may be more appropriately viewed as individual shortcomings for which persons are customarily held responsible. Persons who staunchly fail to help themselves despite repeated opportunities and the threat of dire consequences pose something of a dilemma for applying the deserving/undeserving distinction. Altruistic aversion to others' suffering as well as practical concerns fuel a reluctance to enforce the normative categories to the limits against hard core unfortunates, but strong residual commitment to these norms prevent their wholesale abandonment. One way to reconcile enforcement of personal responsibility with help for the irretrievably ineffectual is to adopt a deterministic stance towards human motivation at the extremes. If intransigent character defects are, in effect, recharacterized as "disabilities"- traits or attributes beyond the control of individuals - then the deserving/undeserving distinction is not threatened by help for the intransigently feckless. This move is not without its appeal: If a person appears unresponsive to abject destitution despite opportunities for improvement, must we not conclude that he cannot help himself? This reasoning also responds to limited information. We lack a complete understanding of human personality and will, and our knowledge of most persons' circumstances is necessarily sketchy. Adopting deterministic or mechanistic explanations for inexplicably self-destructive behavior presents a tempting alternative but results in the inexorable medicalization of what once was considered "bad character." See, e.g., Herb Kutchins and Stuart A. KIRK, MAKIng Us CraZY: DSM, The Psychiatric BIBLE AND THE CREATION OF MENTAL DisORDERS (1997) (noting the proliferation of categories of psychiatric illness in recent years).

91. The TANF statute does not require women with children under six to work more than 20 hours per week, although states can impose more stringent requirements as a condition of cash assistance. See BLOOM, supra note 3, at 114. Most welfare recipients are uneducated and cannot earn enough with part-time work to support even small families. Although the expectation that mothers should work has gained ground, the public is ambivalent about requiring full-time work from mothers of small children. See GILENS, supra note 3, at 178-79 (reviewing attitudes about working mothers); id. at 186, 189 (noting that most survey participants expressed view that mothers of very small children should be excused from work or from working long hours, and that exceptions for welfare time limits should be made "for mothers who work part-time or have preschool children"). When time limits kick in, however, many women will have no choice but to move to full-time employment if they hope to survive without cash welfare assistance. The hardships imposed by these requirements may lead to legislative moves to soften their impact.

There is also a push to roll back harsh restrictions on social assistance for legal immigrants, which were incorporated into the 1996 welfare reform statute. See Kostas A. Poulakidasis, Welfare Reform and Immigration: Attempting to Find a Domestic Answer to a Global Question, 6 IND. J. GLOBAL LEGAL STUD. 283, 313 (1998) (suggesting that limitations on welfare benefits available to legal immigrants serve more to punish individuals who are attempting to become productive members of society than to deter immigration).

92. See, e.g., GILENS, supra note 3, at 193. 
harmed as welfare reform progresses, these sentiments may fuel a move to temper strict welfare rules.

\section{VIII}

\section{Welfare Politics, ReActive AtTitudes, ANd Opposition to Welfare REFORM}

Critics of welfare reform argue that the convictions most people hold do not necessarily comport with what is just, right, or good for society as a whole. To equate the politically popular with the ethically sound is to confound the positive and the normative. If there are good reasons to resist what most people want, public policy should not indulge the majority. ${ }^{93}$

Many proponents of a basic income guarantee, for example, reject the conventional distinction between the deserving and undeserving poor. ${ }^{94}$ The core argument in this article predicts that basic income proposals will generally encounter public resistance, because a rule of "something for nothing" would appear fundamentally unfair to those who work to sustain themselves and others. Proponents of a guaranteed income could seek to counter the perception of unfairness by arguing from other fundamental principles of ethics or justice. ${ }^{95} \mathrm{Al}-$ ternatively, they could adopt a more pragmatic approach by noting that wealthy modern societies can well afford to reshuffle resources more broadly and generously, that there are presently no compelling reasons to honor traditional distinctions in structuring redistribution, and that there are many practical and administrative reasons not to do so. ${ }^{96}$

Because circumstances that limited radical redistribution in the remote past no longer hold, attitudes adopted under those conditions can be viewed as anachronistic. Specifically, the rise of centralized governments with sophisticated taxing power has obviated the need to rely on reciprocal norms to maintain cooperative sharing or any system of resource redistribution. Government coercion, by holding at least some taxpayers hostage to their own self-interest, plays the same role as a coordination convention in the informal context. The key difference between government welfare programs and informal self-help

93. One reason to resist the ordinary politics of welfare is the evidence that voters' views are tainted by racial prejudice. According to Martin Gilens, concern with the poor's deservingness is fundamental, but the application of those concerns varies with voters' beliefs about the welfare population. Many voters think, falsely, that most welfare recipients are black. They also believe that black people are lazier than white people. Voters who harbor those beliefs are more likely to oppose generous welfare programs than voters who do not. See GILENS, supra note 3, at 136-73.

94. On basic or guaranteed income proposals, see supra text accompanying notes 16-17.

95. For further discussion of the theoretical defense of basic guaranteed income, see Wax, Something for Nothing, supra note 18.

96. See, e.g., BRITTAN \& WEBB, supra note 17 (making the case for basic income); ROBERT GOODIN, REASONS FOR WELFARE (1988) (reviewing the difficulties in administering strict tests of need); VAN PARIJS, REAL FREEDOM, supra note 17; VAN PARIJS, ARGUING FOR A BASIC INCOME, supra note 17 (1992) (rehearsing virtues of basic income programs, including ease of administration, elimination of a "poverty wall," minimizing inefficient incentives to "work too much," and expansion of "real freedom for all"). 
organizations is that the former do not permit participants the right of exit. Citizens cannot refuse to support official programs at will. The government forces everyone to contribute resources to designated recipients, whether they like it or not, on terms set by the central authority. Because our society operates according to the standard liberal convention that the choice to enter the labor market is for the individual, ${ }^{97}$ a person can avoid cooperating with the scheme (that is, avoid paying taxes that go into other people's pockets) only by earning very little or nothing at all. The price of noncooperation is to remain poor oneself. This confronts individuals with a hard choice between earning a good living while being forced to subsidize others, or forgoing self-improvement altogether.

This analysis suggests why a generous welfare system might represent a stable option within a modern industrial society despite a considerable amount of free-riding. Although redistribution would appear to discourage production, individual variations in work ethic as well as tastes for leisure, unpaid work, money, and consumer goods will determine actual responses to economic opportunity and tax rates. ${ }^{98}$ If average productivity is high and rewards for effort rise steeply, many will continue to work hard despite substantial redistribution of their earnings to the less unproductive. The system will not unravel or collapse and the difference in overall social wealth with or without substantial redistribution may be quite small. ${ }^{99}$

97. That a society should allow individuals the freedom to decide whether or not to be employed, and at what jobs, is a basic assumption of liberal political theory. See, e.g., RAWLS, supra note 10; Richard Arneson, Is Work Special? Justice and the Distribution of Employment, AM. POL. SCI. REV. 83 (1990); Richard Arneson, Property Rights in Persons, 9 Soc. PHIL. \& POL'Y 201 (1992); Ronald Dworkin, What is Equality II: Equality of Resources, 10 PHIL. \& PUB. AFF. 283, 313 (1981); see also Wax, Something for Nothing, supra note 18. Of course, if the welfare system offers nothing to the voluntarily unemployed, most people will be faced with the stark choice between working and starving. Although some may regard that choice as really no choice at all, the relevant distinction for purposes of our argument is between a negative and positive conception of liberty-that is, between the direct requirement, backed up by state sanctions, that a person take a job, and a system that leaves persons to the economic consequences of their choices.

98. These observations are a staple of public finance, tax theory, and labor economics, which describe substitution and income effects as individual responses to changes in yields from work effort. See generally HANDBOOK OF LABOR ECONOMICS (Orley Ashenfelter \& Richard Layard eds., 1986).

99. For a more detailed exposition of this point in considering basic income proposals, see Brian Barry, Equality Yes, Basic Income No, in VAN PARIJS, ARGUING FOR A BASIC INCOME, supra note 17, at 128. See generally VAN PARIJS, ARGUING FOR A BASIC INCOME, supra note 17. For a discussion of the economic consequences of the welfare state in modern western countries, see A.B. ATKINSON,THE ECONOMic CONSEQUENCES OF Rolling BACK THE Welfare STATE (1999); Nicholas Barr, Economic Theory and the Welfare State: A Survey and Interpretation, 30 J. ECON LIT. 741 (1992) (describing the incentive effects of transfers); see also GoODIN, supra note 96, at 232-33 (reporting on studies showing that levels of taxation imposed to support the welfare state in Western societies have very little effect on work effort); see generally ROBERT E. GOODIN, BRUCE HEADEY, RUUD MUFFELS, HENDJAN DIRVEN, THE REAL WORLDS OF WELFARE CAPITALISM (1999) (finding little correlation among Western industrialized nations between economic growth, per capita income and wealth, and programs of economic redistribution).

Not every society can afford to bankroll a universal or unconditional means-tested guaranteed income at a comfortable or even subsistence level. Some economies simply generate too little surplus wealth. Depending on circumstances, preferences, and culture, even a prosperous economy may be unable to support a subsistence guarantee because work effort at the low or high end of the earnings 
This account suggests that some evolved aspects of human psychology may have outlived their usefulness. The replacement of spontaneous order with law may have rendered the distinction between deserving and undeserving citizens obsolete. The conventions of reciprocity are no longer necessary to stem the defections that threaten to destabilize voluntary cooperative ventures because defections can be blocked by force. The hostage-taking potential of centralized coordination obviates the need to honor the rule of reciprocity. Elemental notions of social obligation need no longer constrain the design of social policy.

If the dominant desert-based ideology might be justified neither by basic principles of justice nor by the limits of economic feasibility, why trust welfare policy to popular will? The contention that conventional sentiments should be disregarded raises serious questions about the relationship between law and psychology. The "ease with which people assume the behavior of Homo reciprocans" $" 100$ and the historical volatility of programs that flout basic reciprocal expectations suggest that policies that run contrary to elemental notions of fairness will not be able to sustain widespread popular support in the long run. This begs the question of whether such programs could ever secure a firm place in democratic societies and of how such a result could ever be brought about.

The suggestion that innate habits of thinking and feeling place constraints on the design of social programs assumes that there is a core of human nature that is not wholly constructed or manipulable. As stated by Samuel Bowles and Herbert Gintis, "the human mind is not a blank slate that is equally disposed to accept whatever moral rules are presented to it by either dominant elites or egalitarian reformers." 101 Although there may be rules that "can be imposed ... with some difficulty," there may be others that "cannot be imposed in any stable manner at all."102 Ingrained habits of thinking may render some policies infeasible, politically or otherwise, in a society based on consensus and committed to consent.

That social institutions must take certain bedrock features of human psychology as a starting point is not an unknown principle, even among theorists who avoid talk of human nature. In A Theory of Justice, for example, John Rawls takes as given that persons will make labor-market decisions on the basis of economic self interest. That assumption is critical to Rawls's adoption of the "difference principle," which only permits inequalities that make the leastadvantaged better off. However, the potential for economic inequality to improve the lot of the worst off assumes that the talented will work harder for greater material rewards and will scale back effort if offered less. G.A. Cohen,

scale may drop off too much. On the other hand, even if work effort does diminish somewhat, a sufficiently wealthy society might be able to tolerate a substantial number of persons out of the workforce without economic or political destabilization or even without a significant compromise of living standards. Although guaranteed incomes almost certainly produce inefficiency, the sacrifice of some efficiency for equity is a tradeoff that a society might well choose to make. See, e.g., Barry, supra, at 128.

100. Bowles \& Gintis Reciprocity, supra note 28, at 21.

101. Id. at 20.

102. $I d$. 
for one, has questioned Rawls's decision to indulge this premise about people's responsiveness to economic incentives. ${ }^{103}$ Cohen's objection begs the question of how it might be possible to suppress the widespread impulse to work harder for more (or less hard for less). ${ }^{104}$ Even if steps could be taken to achieve this result-by, for example, imposing severe sanctions, backed by the state's coercive power, for inegalitarian behavior-the question is whether that effort would ultimately prove effective or whether its success would come at too great a cost to other important values or freedoms.

Arguments based on human nature are contrary to a rational approach to politics, which is reluctant to recognize limits on what governments can achieve based on what most people tend to believe or accept. ${ }^{105}$ Those who reject the idea of innate propensities see no obstacle to adopting rules that are derived from the exercise of rational faculties. But even if persons harbor psychological tendencies, perhaps these can be altered by appeals to reason or to practical concerns. Compelling arguments might succeed in quelling the old resentments or reducing their influence.

What is clear is that opponents of welfare policies that are grounded in popular attitudes must find some way to resist popular will. Securing countermajoritarian shelter for welfare rights by elevating them to constitutional status is one strategy for holding common passions and prejudices at bay. There are reasons to believe, however, that this strategy will not work or will succeed only at a cost that outweighs the benefits. This analysis draws on historical evidence and scholarship suggesting that constitutional guarantees are ultimately powerless against some entrenched social values to which they are opposed. The question is "which values?" Not all popular convictions of the moment persist and some entrenched prejudices fade with time, so speculating on the intransigence of widely and firmly held views is always risky. Although the law's ability to influence attitudes undeniably varies with the attitudes at issue, this paper suggests that deep-seated notions of fairness would appear to be among the least promising candidates for circumvention by law. Because a guarantee of unconditional welfare rights runs contrary to basic norms of reciprocity, it would be difficult to impose that guarantee by constitutional fiat. The suggestion is that the "moral sentiments" that oppose such a regime would ultimately rebel against it and fatally undermine it in the long run.

103. See G.A. Cohen, Incentives, Inequality, and Community, in THE TANNER LECTURES ON Human Values (1992); see also G.A. Cohen, Where the Action Is: On the Site of Distributive Justice, 26 PHIL. \& PUB. AFF. 3 (1997).

104. See, e.g., JOSEPH CARENS, EQUALITY, MORAL InCENTIVES, AND THE MARKET: AN ESSAY IN UTOPIAN POLITICO-ECONOMIC THEORY (1981).

105. See Owen Jones, Sociobiology and the Law of the Law's Leverage, presented at the Olin Conference on Law and Sociobiology, at the Georgetown Law Center (Apr. 1999) (unpublished manuscript, on file with author); John McGinnis, We the Primates (1999) (unpublished draft on file with author). 
IX

\section{WiLl the Constitutional Right to Welfare CHANGE ANYTHING?}

The conventional understanding of constitutional rights is that they should stand as a countermajoritarian bulwark against the vicissitudes of ordinary politics. They are thought to function as trumps, or absolute protections, against majority will. ${ }^{106}$ But some scholars have questioned the power of constitutional commands to enshrine an order that runs contrary to strong popular sentiment or to effect changes opposed to powerful social or political forces that operate independently of the law. ${ }^{107}$ The claim is that constitutional texts that are meant to stand against the majority do not, in the long run, succeed in accomplishing that purpose. This is not to say that constitutional rulings have no influence at all-they may speed progress or temporarily alter its direction or form. But the fundamental trajectory of change is ultimately set by social and economic forces that are largely beyond the reach of the law. In the long run, constitutional commands make little difference to social practice.

A corollary of this thesis is that the judiciary is not as immune from political concerns as ideal theory maintains. Not only will people find ways to subvert unpopular judicial commands, but the judiciary itself will be sensitive to public opinion and social trends. The predicted responsiveness has several possible explanations. First, judges recognize that courts have little practical ability to effectuate unpopular rulings. Because the courts are quite limited in their power to shape and supervise institutions, their remedial reach is often evaded. Second, courts that go too far risk subversion, or even defiance, by agents charged with enforcement or by the targets of their commands. Third, the appointments process tends to produce judges who share views dominant in the community. Although this is not uniformly the case ${ }^{108}$ it may nevertheless be true often enough and will especially be true for matters in which a dominant consensus exists. The fundamental indeterminacy of much constitutional text, if not absolutely necessary for the subordination of constitutional law to politics, helps undermine the potential for a truly countermajoritarian jurisprudence. Broad and vague constitutional commands provide ample wiggle room for

106. See, e.g., DWORKIN, supra note 14, at xi; Sunstein, supra note 14, 736-39.

107. See, e.g., Gerald N. Rosenberg, The Hollow Hope: Can Courts Bring About Social Change? (1991); MARK V. Tushnet, TAKing the Constitution Away From the COURTS (1999); Michael J. Klarman, What's So Great About Constitutionalism?, 93 Nw. U.L. REV. 145 (1998); Gerald N. Rosenberg, The Implementation of Constitutional Rights: Insights from Law and Economics, 64 U. CHI. L. REV. 1215 (1997); Eric Posner, The Evolution of Constitutions (Apr. 5, 1999) (unpublished manuscript, on file with author); David Strauss, Do Constitutional Amendments Matter (Dec. 5, 1998) (unpublished manuscript, on file with author). For a succinct summary of this scholarship, see Richard Posner, Appeal and Consent, NEw REPUB., Aug. 16, 1999, at 36 (reviewing Tushnet's book). For a general illustration of the importance of politics to the application of the Constitution in the area of poor relief, see Diller, supra note 6, at 1401.

108. As Justice Scalia has noted, judges are drawn from a "cultural elite" whose views may diverge from those of the majority. See Roemer v. Evans, 517 U.S. 620, 636 (1996) (Scalia, J., dissenting); United States v. Virginia, 518 U.S. 515, 567 (1996) (Scalia, J., dissenting). 
judges aligned with popular views and invite plausible alternative constructions around which political opinion can coalesce.

The literature discounting the place of constitutional guarantees in political and social life has largely been focused on specific high-profile issues, such as school desegregation, criminal procedure, privacy rights, sexuality, family relations, and free speech. The claim is that litigation has made little concrete difference to mores and practices in these areas. People and institutions have found ways around judicial mandates they cannot abide and have accepted only those they would otherwise support. But what of a constitutional right to economic redistribution? Assuming an unconditional guarantee of economic security appeared suddenly in the Constitution, how much difference would it make if the majority opposed it $?^{109}$ Experience with constitutional economic rights provisions at the state level and in other countries suggests that constitutionalizing welfare rights would not make much difference. There are just too many ways to subvert or modify such a command, and the claims and interests at stake, by their nature, invite evasion.

A number of state constitutions, and that of our nearest neighbor Canada, incorporate language that can be construed to create rights in favor of needy citizens. A recent article surveying state constitutional protections for the poor finds that "twenty three state constitutions recognize that someone or something in the individual states will provide for those in need." "no two constitutional provisions are exactly the same." twenty-three-Alabama, Kansas, New York, and Oklahoma-employ mandatory language imposing an affirmative duty on the state and explicitly identifying the poor as beneficiaries of state action. ${ }^{112}$

When called upon to apply the four strong state constitutional commands, state courts have consistently given legislatures wide latitude in implementing

109. This discussion would appear to beg the question of how welfare rights would ever find their way into the Constitution. If the premise is that most voters would not support these entitlements, where would the impetus to constitutionalize them come from? Although such a development is unlikely, it is not impossible. In the face of extreme corruption, economic inequality, or hard times, citizens might be induced to rally behind such a measure. However, the contention here is that popular support for generous welfare rights would be unlikely to survive a return to more normal times. Alternatively, scenarios can be imagined in which politics—and even constitutional politics-might fail to respect majority sentiment in the short term. Factions that believe in vigorous welfare rights might arise and gain undue influence. $C f$. discussion in note 11, supra. The contention is only that unconditional entitlements are unlikely to survive in the long term. Ultimately, this claim must be tested empirically.

110. Rava, supra note 9 , at 551.

111. Id.

112. See id. at 553-54; ALA. CONST. art IV, $\S 88$ (making it "the duty of the legislature to require the several counties of [the] state to make adequate provision for the maintenance of the poor"); KAN. CONST. art. VII, $\S 4$ (requiring that the state "provide ... for those inhabitants who, by reason of age, infirmity, or other misfortune, may have claims upon the aid of society"); N.Y. CONST. art. XVII, §1 (stating that "the aid, care and support of the needy are public concerns and shall be provided by the state," but allowing this aid to be provided "in such manner and by such means, as the legislature may from time to time determine"); OKLA. CONST. art. XVII, $\$ 3$ (commanding "the several counties of the [s]tate" to "provide, as may be prescribed by law, for those inhabitants who, by reason of age, infirmity, or misfortune, may have claims upon the sympathy and aid of the county"). 
the provisions and have very rarely used them to fault or strike down policies or programs. ${ }^{113}$ In effect, the courts have adopted something like a rational basis standard of review under which policies pass muster if found to be justified by some legitimate government purpose, including minimizing the expenditure of public money. The result has been the refusal to second-guess a broad range of legislative decisions addressing resource allocation, procedural requirements, conditions on participation, time limits, and amount of benefits. ${ }^{114}$

In 1982, Canada adopted the Canadian Charter of Rights and Freedoms, which guarantees equal protection and "life, liberty and security of the person." Canadian supporters of social welfare rights hoped that the Charter would provide a basis for challenging provincial restrictions on social programs, as authorized by new Canadian block grant initiatives. They have urged the courts to apply the equal protection and "security of the person" language to invalidate or modify recent legislation. ${ }^{115}$ As at the state level in this country, constitutional claims challenging legislatively enacted welfare programs have consistently failed, despite the language guaranteeing security of the person. Cases seldom reach the Canadian Supreme Court, and lower courts are generally hostile to attempts to locate affirmative economic rights within the Charter. As a result, Canadian welfare law and the availability of social assistance remain matters almost entirely determined by administrative discretion and statute. ${ }^{116}$

The high degree of judicial deference to legislative constructions of constitutional provisions for the needy could perhaps be ascribed to the language of the particular provisions at issue, which is not only broad and vague but in some cases gives legislatures explicit discretion to design programs to meet constitutional demands. As one commentator has suggested, however, the very ambiguity of the text invites courts to go in a different direction. ${ }^{117}$ Because terms like "need" and "misfortune" are inherently imprecise, they are consistent with an activist construction embracing a broad and unconditional duty to help the needy. Likewise, phrases like "economic support," and "aid, care, and support"

113. See Rava, supra note 9, at 563-64; see also Hershkoff, Positive Rights, supra note 9, at 1144-52 (noting that state courts give deferential review to legislative decisions when interpreting state constitutional welfare provisions); id. at 1169-86 (arguing that state courts should not apply standards developed under the federal Constitution when interpreting state constitutional provisions).

114. See, e.g., Hershkoff, Positive Rights, supra note 9, at 1153-70 (criticizing the state courts' adoption of a rational basis test in applying state constitutional "right to welfare" provisions).

115. See, e.g., Martha Jackman, Poor Rights: Using the Charter to Support Social Welfare Claims, 19 QUEEN'S L.J. 65 (1993) (interpreting the Charter to require judicial action in the face of inadequate social welfare programs); Judith Keene, Claiming the Protection of the Court: Charter Litigation Arising from Government "Restraint," 9 N.J.C.L. 97 (1998) (arguing that judicial hostility to legal challenges to reductions in governmental social spending results from a misreading of the Canadian Charter of Rights and Freedoms); see also Robert A. Sedler, Constitutional Protection of Individual Rights in Canada: The Impact of the New Canadian Charter of Rights and Freedoms, 59 NOTRE DAME L. REV. 1191, 1206 (1984).

116. See, e.g., Jackman, supra note 116, at 66 (noting that courts seldom apply the Charter to vindicate welfare rights despite its providing a "solid basis for challenges to inadequacies ... in social welfare legislation"); Keene, supra note 115, at 109 (noting that few Charter-based arguments have reached the Canadian Supreme Court despite myriad lower court decisions appearing to disregard its terms).

117. See Hershkoff, Welfare Devolution and State Constitutions, supra note 9, at 1412. 
are subject to interpretation. They admit of respectable readings that impose far greater obligations on state governments than those courts have generally recognized.

Yet this is not the path the courts have taken. Instead, they have elected to drain the constitutional welfare provisions of content and to defer almost entirely to the legislatures' judgments of what the basic charters require. The willingness of judges to stay their hand in this area is strong, and stronger than in many others. Although this result is probably overdetermined ${ }^{118}$ the jurisprudential turn may be driven, in part, by the intuition that imposing stringent and unyielding obligations on states would be highly unpopular and would prove at best extremely divisive and at worst unavailing.

Even if the generality of constitutional language does indeed help defeat the countermajoritarian project so that writing more specific provisions might cabin judges, that possibility is unlikely to be tested in practice because greater specificity runs contrary to entrenched conventions of constitutional drafting. It might prove difficult for a constitutional amendment to include enough detail or be sufficiently definite to withstand determined attempts by courts to weaken or subvert its distributional requirements. Although one could, for example, imagine establishing a basic right to unconditional income for all by a clear and bold command ("All citizens shall receive a basic income of amount x"), anything short of such an across-the-board guarantee-and, specifically, any entitlement made conditional on deficiency or "need"-would almost surely require some statutory elaboration and the filling in of many details.

Leaving aside the awkward impracticality of writing a constitution like a statute, there remains a question of whether effective limits on judicial discretion would translate into the delivery of services as dictated. The courts cannot administer public welfare programs on their own. Experience with legislative mandates demonstrates that those charged with executing the law in this area have myriad opportunities to subvert and undermine the rules with which they disagree. ${ }^{119}$ In even the simplest program, there are simply too many judgments

118. Perhaps judges are daunted by the sheer complexity of the considerations that would appear to bear on the design of social welfare program or are humbled by the existence of widely diverging theories, informed by a broad and complex array of factual premises and moral assumptions, about the social and economic origins of poverty and its cure. They may believe that they should not be the ones to choose among the many options available to vindicate the constitutional command, especially since they lack access to pertinent information or the expertise to make policy judgments with potentially perverse consequences. Alternatively, some state judges may fundamentally agree with what the legislature has done and the theory it has embraced in the welfare policy area. Even apart from questions of fairness, they may accept the view that overly generous programs are harmful to the poor and socially destructive.

119. See, e.g., J. L. Mashaw, Welfare Reform and Local Administration of Aid to Families with Dependent Children in Virginia, 57 VA. L. REV. 818 (1971) (detailing resistance to legal requirements and centralized commands under the AFDC programs in different counties in Virginia during the 1970s); see also WINIFRED BELL, AID TO DEPENDENT CHILDREN 29-39 (1965) (describing informal enforcement of illegal "man in the house" and "suitable homes" rules in the South from the 1930s through the 1960s); Mead, Welfare Employment, supra note 57, at 39 (examining the range of bureaucratic practices and outcomes associated with work requirements under the JOBS and WIN programs). 
to be made and administrative parameters to control to guarantee effective oversight and enforcement of an unpopular program.

Would constitutionalization be wholly ineffective? Even the vaguest and broadest constitutional provision would appear to impose some obligations on government. Poor relief provisions in state constitutions are difficult to reconcile with complete government inaction. But as history demonstrates, a constitutional bar to doing absolutely nothing would not so much be futile as unnecessary. Since the mid-nineteenth century, governments at all levels in this country have devoted some resources to reducing poverty and ever greater resources to programs such as Social Security, Medicare, and disability insurance that, although not specifically earmarked for the poor, do much to protect them from destitution. The welfare state and government redistribution are enduring features of the landscape because there is no serious constituency for a complete return to laissez faire. Even with the advent of TANF, there is no real danger that programs for the poor will be shut down. Federal Medicaid and food stamps programs continue in effect, and millions still receive cash welfare benefits. Moreover, states have the option of exempting twenty percent of the welfare population from TANF's time limits and work requirements, which suggests that there will always be a small, non-working population receiving welfare. ${ }^{120}$ A constitutional guarantee is not needed to ensure government action to protect the poor. To the extent that courts appear eager to leave that action to the political branches, such a constitutional provision would have little impact.

\section{$\mathrm{X}$ \\ CONCLUSION}

This discussion suggests that creating a constitutional right to welfare would not prove worthwhile. Politics will ultimately prevail and there is no protection from politics. A fundamental shift in popular sentiment is required. To be sure, we can never be entirely certain whether the categories commonly applied to thinking and feeling about support for the needy are amenable to radical transformation under as yet unanticipated cultural and historical conditions. Yet the evidence continues to suggest that the basic notions of desert and lack of desert, as defined by a reasonable effort towards social productivity or its absence, continue to dominate discourse and emotion. In the absence of a reliable way to reform hearts and minds, the prediction is that arrangements that run contrary to basic reciprocal ideals are unlikely to form an enduring basis for public policy.

In sum, the evolutionary argument in this article suggests that any public scheme that permits individuals to draw upon the product of collective efforts must comport with basic ideas of fairness. Public indignation will eventually catch up with policies that permit citizens to violate fundamental norms of reci-

120. See supra text accompanying notes $85-89$. 
procity by failing to do what is regarded as their "fair share." Although there may be some room for influencing views on what counts as an adequate contribution to the social effort, the potential to modify this notion is not unlimited. The modern welfare state may have no choice but to make peace with human nature. 